\title{
The Cyprus Debt: Perfect Crisis and a Way Forward
}

\author{
Stavros A. Zenios* \\ Department of Accounting and Finance, University of Cyprus \\ and the Wharton Financial Institutions Center, University of Pennsylvania
}

\begin{abstract}
The Cyprus crisis is one of the most complex in the Eurozone -although in absolute terms it is a minor crisis. An analysis of the ongoing developments from different perspectives leads to the conclusion that we are witnessing a perfect storm of a financial crisis at the confluence of sovereign debt and banking crisis together with debt overhang of business and households and a severe decline of competitiveness. As a result Cyprus has amassed a large external debt that cannot be repaid, no matter what fraction of the country's real domestic economic output is appropriated through austerity measures. Hence, fiscal austerity leads to deflationary stagnation and alone does not work. We advocate a policy response that addresses multiple dimensions of the problem with policy options of (1) austerity deleveraging, (2) structural reforms, (3) financial innovations, (4) selective privatizations and (5) debt restructuring. These options are drawn from lessons of what worked well, and what not, in crises of other countries and these lessons are summarized in lieu of conclusions. A postscript discusses the potential impact of the Eurogroup decision of March 2013 on the Cyprus crisis.
\end{abstract}

Keywords: financial crisis, debt overhang, banking crisis, competitiveness, labor cost, GDP-linked bonds, crisis management, Eurozone, Cyprus.

\section{Introduction}

A thick and seemingly impenetrable cloud of debt is hanging over Cyprus. After 30 years of uninterrupted economic growth --with the economy remaining unscathed from the debt crisis of the 1980's and the crises in Asia and Latin America at the end of the 20th century-- growth came to a halt. In May 2011 the country was cut off from international markets. 2011 marks the start of the Cyprus crisis. More than a year later, in June 2012, the Government applied to the International Monetary Fund-European

* Address: Department of Accounting and Finance, University of Cyprus, P.O. Box 20537, 1678 Nicosia. E-mail: zenios.stavros@ucy.ac.cy. 
Commission-European Central Bank (IMF-EC-ECB, the «troika») for assistance ${ }^{1}$.

As the Cyprus economy was put under the microscope of international bodies the picture that emerges is that of a unique crisis. Cyprus, with a GDP of about $€ 18$ billion, represents $0.2 \%$ of the Eurozone economy. Nevertheless, the complexity of the crisis perplexes those searching for a comprehensive rescue package. Notwithstanding the preliminary Memo of Understanding (MoU) agreed between the Government and the Troika in November 2012, the final agreement was reached 271 days after the country applied for assistance. In contrast Greece, Ireland and Portugal had agreed on a program within fifty days.

Statements by EU and IMF leaders reveal significant differences of opinion between the IMF and EC/ECB on the best response to the situation. In Cyprus the management of the crisis was complicated by the outgoing President Dimitri Christofias blaming squarely the banks and banking supervision ${ }^{2}$. The ex-Governor of the Central Bank, Athanasios Orphanides, a noted economist, responded by blaming public finances and the mishandling of the Greek PSI (haircut) and the political debate revolved for months around a public-finance-crisis vs banking-crisis response ${ }^{3}$.

In this paper I do not discuss any of the within-troika differences that complicate the decision internationally and I sidestep the local passing-theblame game. I focus exclusively on the economic and financial aspects of the problem. An important lesson learned from crises in other countries is that «financial ignorance is dangerous» (Schuberth 2011) and the paper contributes in bypassing this trap.

A word on methodology. There is extensive literature that could help us analyze the Cyprus crisis. Debt sustainability can by analyzed with the IMF methodology (Ostry et al. 2010), fragility of the sovereign debtbanking system in a currency union can be addressed using the work of, e.g., (De Grauwe 2012), and we can estimate the impact of austerity

\footnotetext{
1 IMF statement as reported by Reuters:

http://www.reuters.com/article/2012/06/27/us-cyprus-imf-idUSBRE85Q12020120627.

2 This has been the Presidents' opinion about the origins of the crisis and became part of the political discourse, repeated in public statements at home and abroad, see, e.g. http://www.ekathimerini.com/4dcgi/_w_articles_wsite2_1_04/12/2012_472971 and http://www.bloomberg.com/news/2013-01-15/cypriot-president-christofias-decries-eustrict-austerity-.html.

3 Statement made by the Governor to the House Finance Committee after his term was not renewed by the President.
} 
measures using econometric models. All these approaches have merit and most likely will be undertaken in the coming months. However, each one applies, assuming the underlying model structure and key parameters remain unchanged. However, it is virtually impossible to get accurate data for economies that are in a crisis, as the situation on the ground is extremely dynamic. Also, like all models, they produce predictions and error estimates given some modelling assumptions. The solution could be sensitive to the response of the economy to the implemented policy and to any other policies adopted simultaneously. In times of crisis the system is highly reflexive and we are dealing with partial equilibria of an unstable system. A case in point is the debate going on as these lines were first written (January 2013) on the sustainability of Cyprus sovereign debt. The answer depends on the estimates provided by PIMCO for bank recapitalization, and those depend on the assumptions made for the economy and especially the real estate market. These, in turn, do not take into account how any policies adopted based on the estimates will affect the assumptions as no policy has been articulated yet.

The insights for policymaking obtained from any single model are limited. The mantra «the purpose of modeling is insights, not numbers» applies particularly in times of crisis. There are no simple fixes to complex problems and Greece exemplifies this point. The country went through three MoU's before any positive effects started to be noticed. While Greece is blamed for lack of political resolve in the early stages, certainly an important factor in crisis management, it is also the case that the original policies did not fully comprehend the complexity of the problem and they were based on underestimates of the impact of austerity on growth. (Blanchard and Leigh 2013) find that forecasters had consistently underestimated the effect of austerity on growth. Fiscal multipliers that were of the order of 0.5 under normal times are found to be close to 1 under crisis conditions. Among the many factors explaining the upward revision of the multipliers is the interaction of multiple adverse conditions.

In the light of this critique, this paper provides an analysis of the Cyprus situation from different perspectives: it identifies the dimensions and magnitude of the crisis and the ability of the economic agents to service their debt, it discusses solvency in a currency union, and compares with other Eurozone crises countries.

The analysis leads to the first point of the paper: a diagnosis of a «perfect crisis» at the confluence of sovereign debt and banking crisis together with a debt overhang of business and households and a severe decline of competitiveness. At this confluence Cyprus has amassed a large external 
debt that cannot be repaid no matter what fraction of the country's real domestic economic output is appropriated through austerity measures. Revenues can only be used to pay external debt to the extent that they accrue from export revenues, or if the foreign creditors use payments to acquire domestic goods and services or domestic assets. If this is not the case, then there is an inconsistent flow of funds with the flow of goods and services. This inconsistency ultimately leads to default on external debt or domestic sector bankruptcies and forced reallocation of resources to the export sector with potential loss of efficiency. These were the arguments made by (Keynes 1920) in explaining the futility of reparation payments by post-WWI Germany. Recently they have been used to explain the crisis in the Eurozone periphery, see, e.g., (Cabral 2011).

Based on this observation the paper makes its second point: the need for a multi-faceted response to the crisis. Austerity alone can not solve the problem. However, other policy options in their pure form are either politically unacceptable or unlikely to be effective. Thus I argue for the flexibility created when multiple options are combined, allowing fair sharing of costs and creating space for the government to deal with the accumulated problems.

The paper has three main sections. First, I put the Cyprus crisis in a broader historical context, then I carry out the analysis of the situation and finally I discuss the policy options. I conclude by drawing lessons from other countries and with a short postscript on the eurogroup bail-in decision reached after my paper was first posted.

\section{The Cyprus crisis in a historical context}

As much as Cyprus has been remarkable in presenting a crisis of unique complexity, it has also been unique in experiencing a prolonged period of stability accompanied by growth. Since its recovery from the 1974 Turkish invasion and until the start of the current crisis, the average GDP growth has been $4 \%$ and unemployment $3.5 \%$.

Since independence in 1960 the country experienced none of the crises described in the seminal book by (Reinhart and Rogoff 2009), henceforth abbreviated as (RR). There was one asset bubble crisis in the stock market in 1999 but although in percentage decline this was one of the largest bubble-bursts of the later part of the 20th century, it did not affect growth or unemployment. The Cyprus Stock Index grew from a capitalization of $€ 1.8$ bil. in 1996 to $€ 24$ bil. by the end of 1999 and then dropped by $60 \%$ to 
$€ 9.6$ bil. in two years. During the bubble years the economy grew by a total of $12 \%$ and an additional $11 \%$ three years after 19994 . Unemployment went up by about 1.5pp --this was a significant increase at the time-but reverted to its long term trend within two years. Not much of a crisis to talk about, although wealth redistribution must have been substantial as $43 \%$ of households were invested in stocks and the average household invested 83\% of its annual income. As (Orphanides and Syrichas 2012) p.287 point out «losses from the stock market crisis did not affect consumer demand. This is due to the fact that most of the own-money invested in the market were earmarked for future, and up to that moment, unspecified needs.»

In their analysis of data from «eight centuries of financial folly», (RR) show that debt crises are not uncommon and from (RR, Table 5.1) we calculate some statistics to compare the Cyprus experience with other countries:

\section{Time to default since independence}

Cyprus is virtually in default for the first time 51 years after independence. Compare with the experience of others from Table 1 below.

\section{TABLE 1}

Time to default since independence

Average years to default and rescheduling for 31.5

African and Asian countries

Average years in between defaults and

36, including Great Depression

rescheduling for Latin American countries

38, excluding Great Depression

\section{Share of years in default and number of defaults}

To compare with countries that have a very different historical experience than Cyprus' colonial past we compare the share of years in default or rescheduling since 1800 and the total number of events from the simple averages below.

\footnotetext{
${ }^{4}$ Data from World Economic Outlook Reports, IMF; GDP growth in constant prices.
} 
TABLE 2

Share of years in default or rescheduling since 1800

\begin{tabular}{ll}
\hline Share of years in default or rescheduling for European countries & $14.3 \%$ \\
Number of defaults or reschedulings & 3.8 \\
Share of years in default or rescheduling for European countries that defaulted & $22.8 \%$ \\
at least once & 6.1 \\
Number of defaults or reschedulings & \\
Share of years in default or rescheduling for Latin American countries & $34.7 \%$ \\
Number of defaults or reschedulings & 7.0 \\
\hline
\end{tabular}

Scaling these data to match Cyprus' half century of independence, we note that European countries that did default have on average 1.5 default events and Latin American countries have 1.75 events per half century. By comparison Cyprus has 1, and if the current crisis lasts five years its share of years in (virtual) default will be $10 \%$ which is significantly lower than the averages.

These statistics provide some comfort that the situation of Cyprus is not unique. Indeed, the country has been a positive outlier among the victims of excessive indedebtness. This observation should be kept in mind when designing policies. Not so much as a mitigating factor that the country has a "clean record», but in the sense that empirical evidence supports the folklore that Cyprus economy is resilient. Another observation that adds credibility to this claim is the strong recovery after the 1974 war -although the circumstances and prescribed solutions are very different today.

These comparisons may also explain why the political and banking elites developed blind spots. They believed in the «in-vulnerability of the economy» -to quote the President ${ }^{5}$ - and the result is a perfect storm of a debt crisis. To paraphrase Reinhart and Rogoff «this country is not different».

\section{The Cyprus crisis dissected}

Crises triggered by excessive debt are solved by a long and painful process of deleveraging during which the over-indebted sector of the economy households, corporations or the government- scales down its debt. The other sectors accumulate debt during this period to avoid a prolonged

\footnotetext{
5 Statement by President Christofias on 14 Oct. 2008 http://www.moi.gov.cy/moi/pio/pio.nsf/All/96B5486A29CA4EBDC22574E2003740C3?O pendocument\&print.
} 
recession. Once the over-indebted sector deleverages and growth resumes, the newly acquired debt gradually becomes less significant as a proportion of the GDP. The following policy responses apply:

1. Expansionary fiscal policy: it increases government spending to provide economic stimulus while households and/or corporations deleverage.

2. Inflation: it erodes the real value of debt.

3. Currency devaluation: it reduces home-currency denominated debt burden through an acceleration of inflation while boosting exports and growth depending on demand and supply elasticities.

4. Growth led recovery: accelerated economic growth makes debt less significant with respect to GDP; above-average growth can come from exploitation of natural resources or the end of a war.

5. Default or debt restructuring: it reduces debt burden, either unilaterally (Argentina in 2005) or in negotiated agreement with creditors (Greek private sector haircut 2011 and official sector loan renegotiation 2012, Ireland loan renegotiation 2013).

If the debt crisis is combined with a banking crisis the problem gets more difficult to handle. Of course banking crises are (usually) caused by excessive debt but it need not always be the case that excessive debt leads to a banking crisis. However, if a debt problem triggers a banking crisis then a vicious circle is set into motion whereby credit crunch exacerbates the debt problem that created the credit crunch in the first place (Mody and Sandri 2011). «Financial crises rather than being a trigger of recession, they are more often an amplification mechanism» (RR, p. 145).

If the crisis develops in a member of a currency union, then no devaluation is possible. Inflation is also not an option if most (or the strongest) members of the union favor low inflation. Furthermore, we witness a flight of capital from the crisis country.

With this background in mind we ask two questions: "What exactly is happening in Cyprus?" and "What are the available policy options?"

First we give some benchmarks to use for laterfcecc comparisons:

- (Cecchetti, Mohanty, and Zampolli 2011) of the Bank of International Settlement estimate that non-financial institutions debt over $250 \%$ of GDP is a drag on growth.

- Government debt beyond $85 \%$, corporate debt beyond $90 \%$ and household debt beyond $85 \%$ is a drag on growth. 
- The median non-financial sector debt of OECD countries at 2010 was $322 \%$ of GDP.

Excessive aggregate debt may slow down growth, but by itself is not an indicator of impending crisis. Many other factors come into play as we analyze below. It is worth noting here the use of more modest benchmarks than the seminal --and by now infamous--(Reinhart and Rogoff 2010). In particular I do not subscribe to the notion that there is a universally applicable threshold of debt beyond which a national economy shrinks; their $90 \%$ threshold was discredited by the recent findings of (Herndon, Ash, and Pollin 2013). Instead the benchmark I use suggests that as debt increases, growth maybe suboptimal which is consistent with the more recent findings.

\section{Dimensions and magnitude of the Cyprus crisis}

Aggregate statistics of the Cyprus debt in 2011 are summarized in Table 3:

\section{TABLE 3}

Cyprus aggregate debt in 2011

\begin{tabular}{lll}
\hline Debt & In millions euro & As \% of GDP \\
\hline Government & 12.777 & 71 \\
Corporate - non financial & 27.865 & 155 \\
Household & 23.928 & 133 \\
Financial institutions & 4.331 & 24 \\
\hline
\end{tabular}

Source: Eurostat.

Figure 1 shows the debt composition as a percentage of GDP over the last 15 years. Excluding the debt of financial institutions, the country's debt at $359 \%$ stands, as of 2011, 37pp higher than the OECD median. We note that from Central Bank of Cyprus data the debt of domestic non-financial corporations is 23.007 euro, which makes the domestic non-financial debt $333 \%$ of GDP. The difference between domestic and non-domestic debt may be significant for a country like Cyprus whose banking sector is disproportionately large to its economy, but in the absence of additional data from other OECD studies we work with aggregate debt. We also note that if aggregate debt is adjusted for the size of the shadow economy of Cyprus-which at $28 \%$ of GDP is 10pp higher than the OECD average (Schneider, Buehm, and Montenegro 2010)- then Cyprus aggregate debt is like the average of developed economies. 
Comparing Cyprus data with the benchmarks we observe that aggregate debt has exceeded the level beyond what is considered a drag on growth since 2003. The heavy debtors are non-financial corporations and households. Historically, debt/GDP growth has been almost identical to the international average of 5\%. Since joining the euro however in 2008 debt increased rapidly by $69 \mathrm{pp}$ including $22 \mathrm{pp}$ increase for government.

\section{FIGURE 1}

\section{Composition and growth of the Cyprus debt}

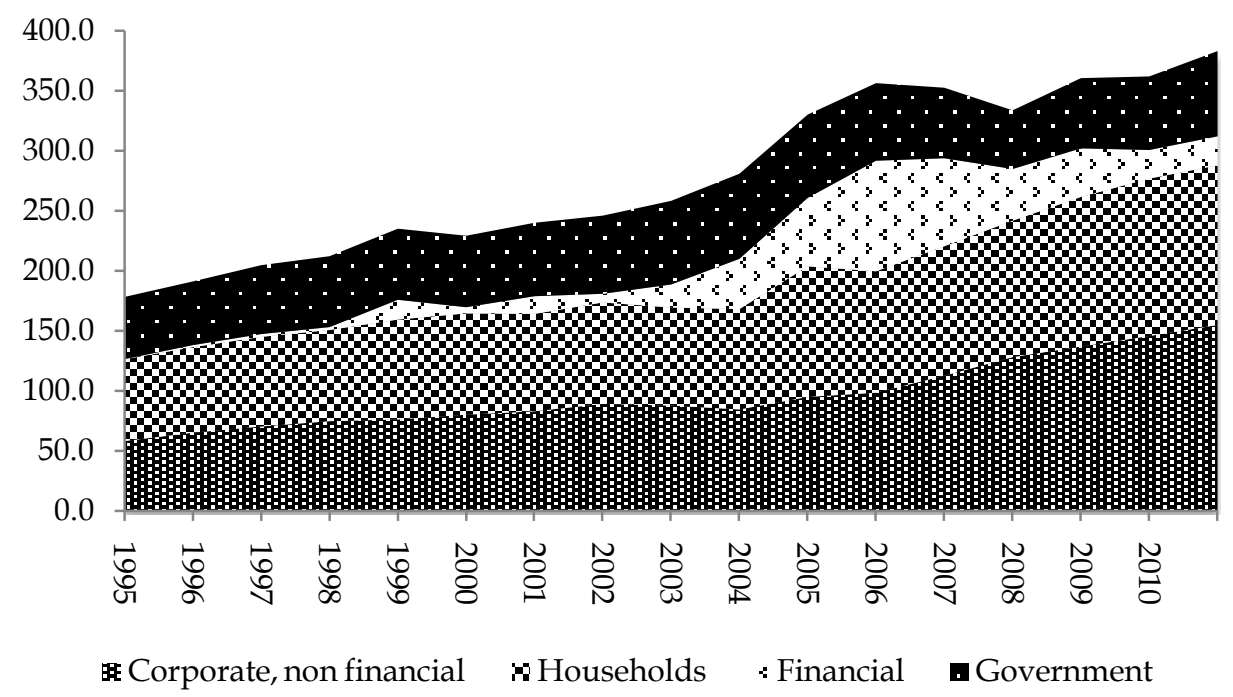

Source: Eurostat.

At the onset of the 2008 international crisis, government debt was not exceeding the threshold but two observations are important:

1. Since 2001 government debt exceeds the $60 \%$ Maastricht limit with the exception of the three year window around the entry to the Eurozone.

2. In most mature economies the government debt prior to the crisis was flat or even declining and this facilitated crisis-related public spending, while the Cyprus government spending accelerated as the crisis was developing. In 2007 the public debt of Ireland, Spain and Cyprus were, respectively, 25\%, 36\% and 59\% of GDP, (McKinsey 2010) p.10 and Eurostat.

Let us look at the debt dynamics around the time of joining the Eurozone. A debt surge by financial institutions and households contributed to a reduction of government debt to satisfy the Maastricht criteria. This was the result of increase in government revenues due to the real estate bubble. 
Since joining the EU in 2004 the government expenditure declines marginally from about $42 \%$ of GDP while government revenues increased by $5 \mathrm{pp}$. But this had not been a sustainable situation and public finances deteriorated rapidly after 2009.

Ownership of public debt is $59.6 \%$ domestic and $41.4 \%$ foreign, see Figure 2 . This split is balanced and not atypical among EU countries. However, the net international investment position (NIIP) of Cyprus at 2011 was $71.3 \%$ of GDP, see Figure 11. On the positive side, internal ownership of public debt implies that debt repayment stays in the local economy and the government also collects taxes on its payments. On the negative side, there is not much room for debt restructuring as any relief will be absorbed by local banks and the state would have to cover additional losses. So, with a NIIP at $-71.3 \%$ of GDP some form of debt restructuring might be needed, but with $59.6 \%$ domestic, effective restructuring is impossible. Cyprus is caught between a rock and a hard place.

\section{FIGURE 2}

Domestic and foreign ownership of CY public debt

(Total EUR 15.316 mil.,2012)

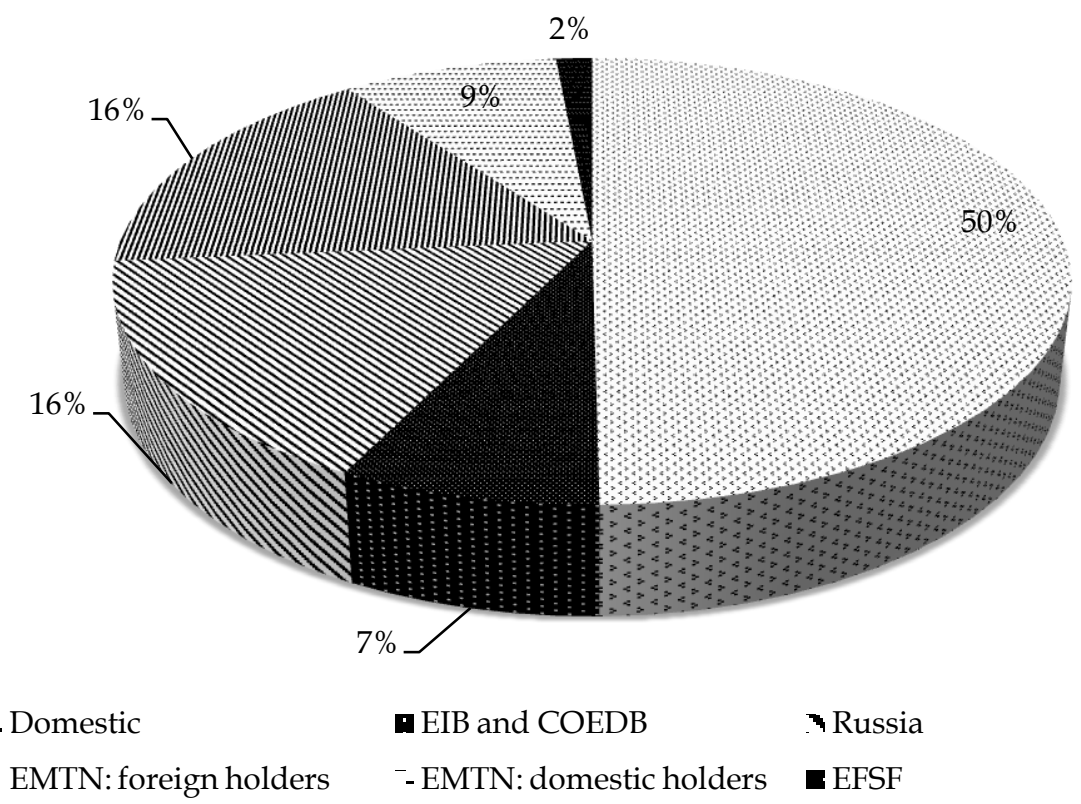

Source: Estimated \% by Sapienta Economics based on data from Ministry of Finance. 
While these levels of debt are reason for concern, the magnitude of the problem cannot be fully appreciated until we assess the ability of the debtor to service it. Debt in excess of a threshold may be suboptimal but is not necessarily a sign of impending crisis. We therefore look at the ability of the economic agents to service their debt.

\section{The ability of households to service their debt}

We compare the growth of aggregate per capita debt of households with gross disposable per capita income. Figure 3 and 4 shows a clear divergence between debt and income, with average growth, respectively, by $0.5 \%$ and $5.4 \%$ during the last decade. Cyprus has the highest household indebtedness in the Eurozone as a percentage of GDP, but this is covered by substantial assets and the household sector had -until 2010positive net asset position (European Commission 2013), p.24. However, high debt stock increases the vulnerability to shocks and the fact that assets are less liquid in Cyprus than in the rest of the euro area increases this vulnerability. With declining interest rates since deregulation, the debt might have been affordable but in the current crisis it is less so. The share of interest payments to disposable income is the second highest in the eurozone and with growing unemployment and illiquidity of assets, deleveraging of households looks unavoidable.

\section{FIGURE 3}

The debt stock of the household sector

(Per capita debt and income)

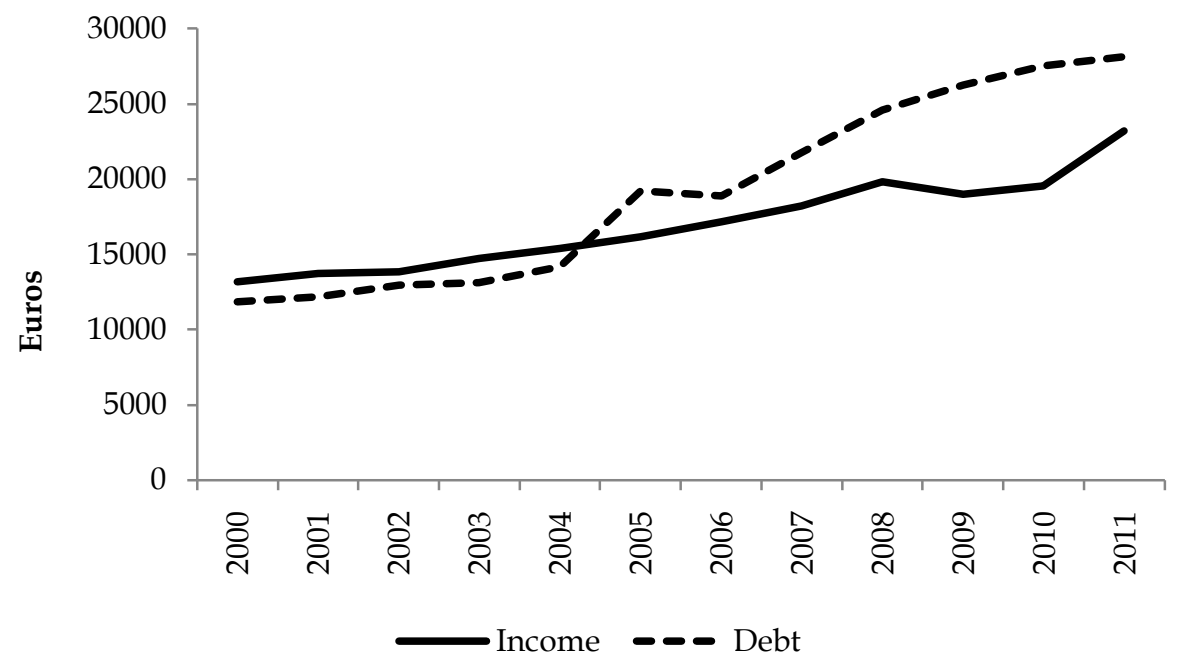

Source: Eurostat. 
FIGURE 4

The debt stock of the household sector

(Fraction of income paid on interest)

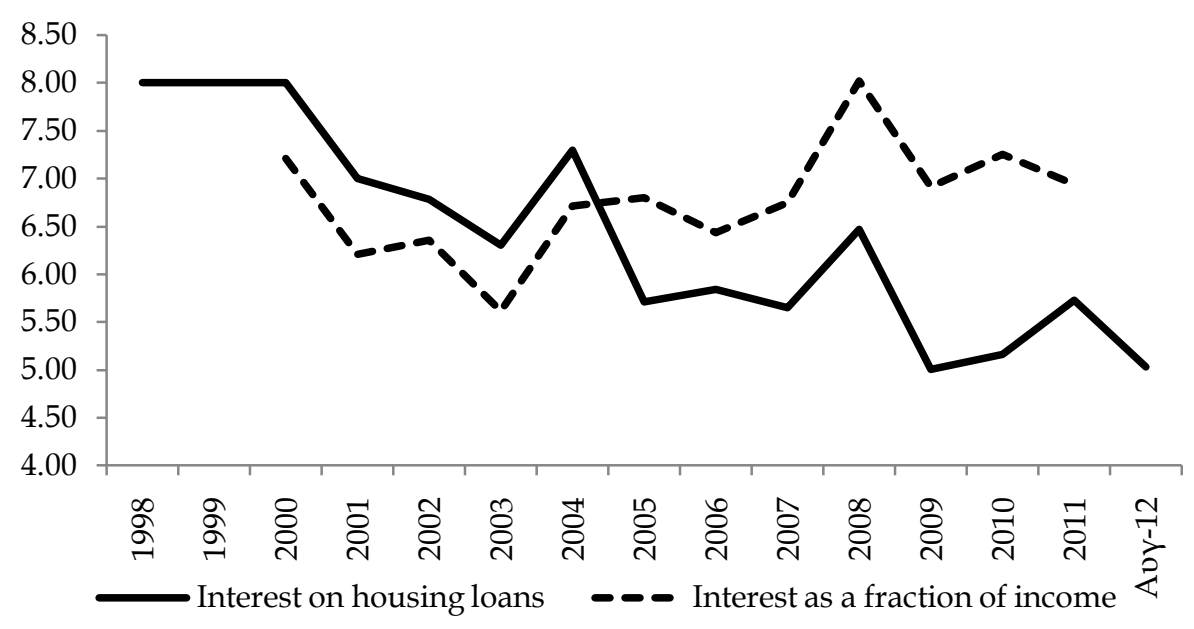

Source: Eurostat.

\section{The ability of corporations to service their debt}

For corporations we compare debt-to-equity ratios. We do not have book equity data for non-listed firms, therefore we use as proxy the ratio of debt to total capitalization of listed companies. Figure 5 illustrates the trend but leverage ignores the equity of non-listed companies. However the dramatic increase of leverage since the onset of the international crisis could have been reversed only with an equally dramatic increase in equity by non-listed firms. This is very unlikely during a crisis and there is no evidence to suggest any such trend in the Cyprus industry. A study by the (European Commission 2013) p.26-27 reports about constant debt-to-book equity and debt-to-assets ratios for non financial corporations. We find this observation at odds with our own estimates as Figure 4 illustrates: market capitalization during 2008-2011 has been approximately at the same levels like the pre-boom period 1999-2005, while our proxy of the debt-to-equity ratio has increased significantly from 2-4 (pre-boom) to significantly higher than 4 post-boom. Comparing leverage trends with total market capitalization we conclude that the improvements in leverage during 20042008 were mainly due to stock market rally, while the substantial increase in leverage post-2008 can not be explained by declining stock market prices. The rapid increase in leverage is predominantly due to increasing indebtedness than to a decline of the general stock market index. Consistent with our observation the Commission study also reports that 
Cyprus companies have negative financial position, profits have been weak and non-performing loans have been on the rise from $7.4 \%$ in March 2010 to $10.1 \%$ in September 2011. High levels of corporate indebtedness hold back investments and are a drag on growth. With tightening bank credit, deleveraging of the corporate sector should be expected.

\section{FIGURE 5}

\section{A proxy of debt/equity ratio for corporations}

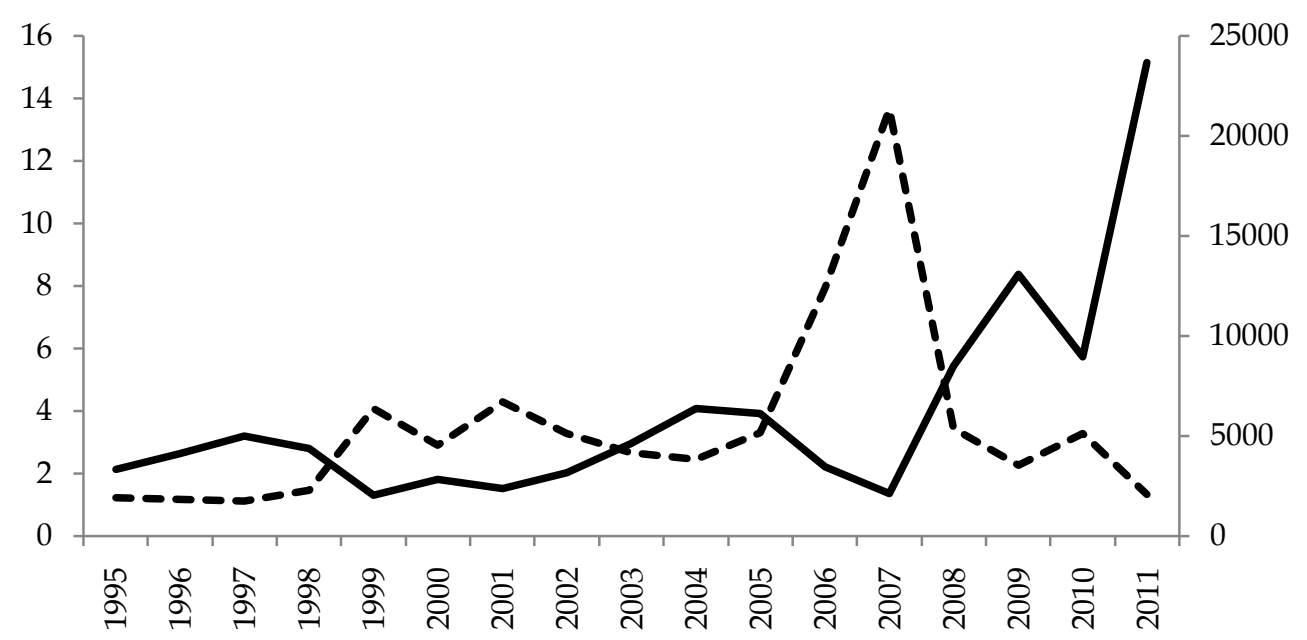

—Debt/equity (left axis) _ _ - Market capitalization (ight axis), mil. USD

Source: The World Bank on market capitalization and author's calculations.

\section{The ability of government to service public debt}

We compare debt levels with aggregate tax and social contributions income. Figure 6 shows the debt-to-taxes ratio. It is higher than the 1.8 average ratio of 20th century episodes of default calculated from (RR), Table 8.1. The situation improved just before joining the euro but deteriorated rapidly afterwards. This is another manifestation of the phenomenon we observed before: households and corporations financed the government on its way to the Eurozone. This would have been fine if the accumulation of debt did not continue unabated. 


\section{FIGURE 6}

The ability of government to repay its debt (Debt/Taxes)

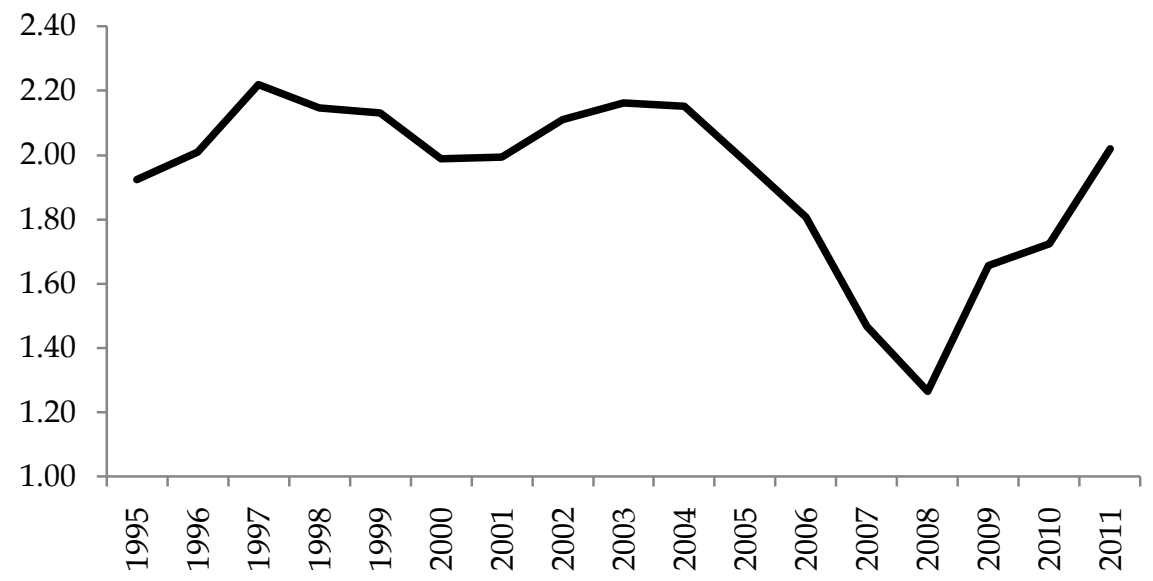

Source: Eurostat.

\section{Banking hubris}

The banking sector of Cyprus entered the 2008 international crisis on sound footing, Figure 7. By 2011, debt of financial institutions stood at $24.1 \%$ of GDP, which is about the average of mature economies $(23.6 \%)$ and much lower than that of Ireland or Spain $(259 \% \text { and } 50.7 \%)^{6}$.

\section{FIGURE 7}

\section{The debt of financial institutions}

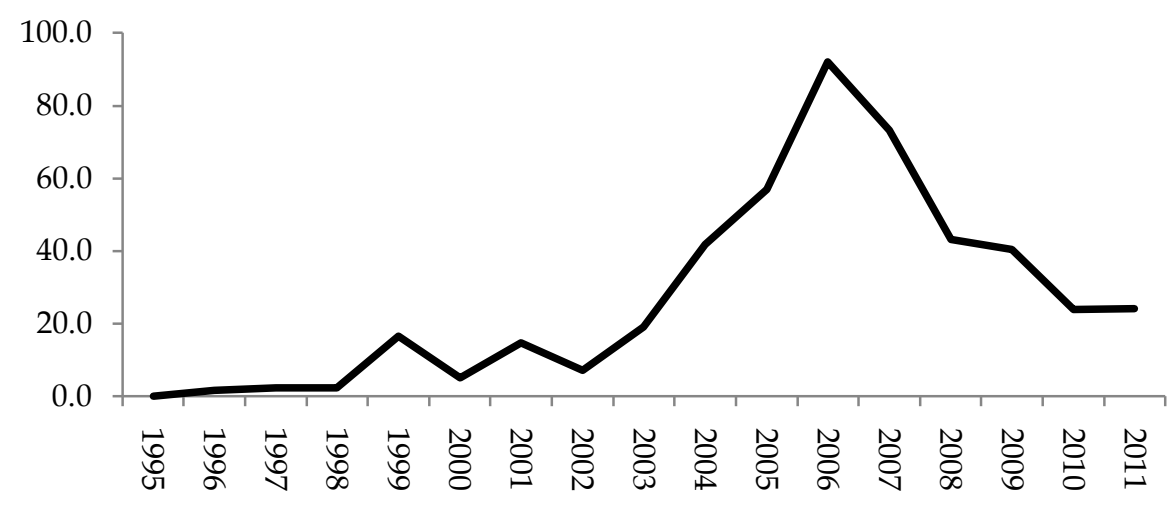

Source: Eurostat.

${ }^{6}$ Data for Cyprus and Spain are from Eurostat, reported for "other monetary financial institutions" and referring to "securities other than shares". For Ireland, Eurostat does not report any data and the number is obtained from (McKinsey Global Institute 2012), Exhibit E4. 
Loans were funded by deposits with loan-to-deposits LTD ratio about 1. However, if we were to estimate the ratio for residential loans and deposits we find a significant increase from 1.4 in 2006 to 2.1 by 2013 indicating significant financing with foreign deposits. Indeed, Figure $8 \mathrm{a}$ and $8 \mathrm{~b}$ shows the large inflow of funds to the Cyprus banking sector starting at about the time of joining the EU. By the time the crisis hit more than one third of bank deposits were from non-residents.
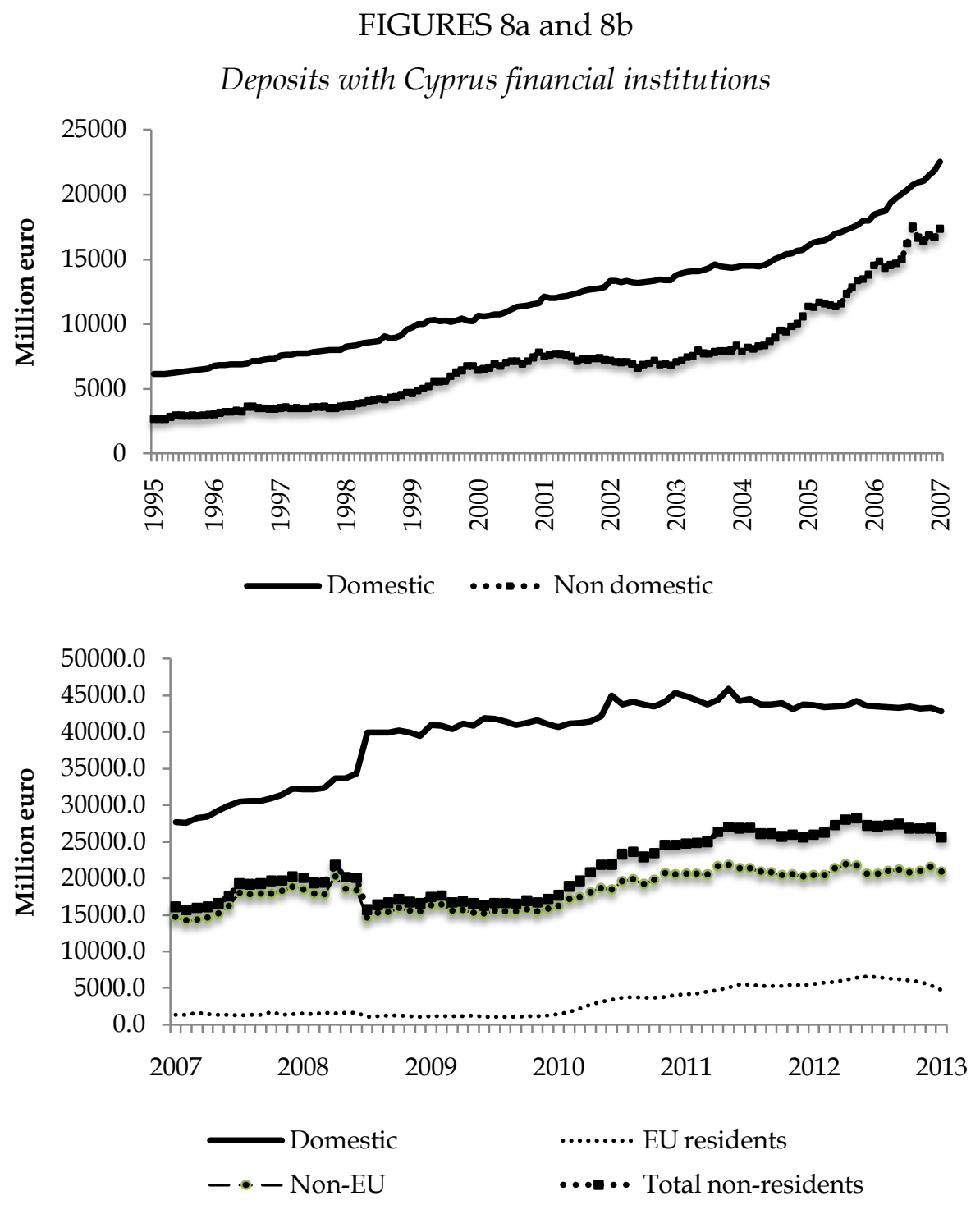

Note: Top and bottom figures refer to different time periods and the classification of domestic and non-domestic is not identical during these periods so some discontinuity is present. Nevertheless the trends are clear. 
In addition to rapid liability growth the banking sector was facing significant risks on the asset side that did not register on the radar of the supervisory authorities and bank management -or if it did, the response was inappropriate or negligent.

1. Banks had excessive concentration risk with total exposure to Greek loans and sovereign debt worth 160\% of GDP. (One of the local systemic banks had 100\% Core Tier 1 capital in Greek bonds.)

2. The Cyprus banking sector has total liabilities about $700 \%$ of the country's GDP and is dominated by two banks that are both «toobig-to-fail» and «too-big-to-save».

3. Deposits in excess of $150 \%$ of GDP are from foreign nationals and capital flows tend to be pro-cyclical, increasing volatility and exacerbating problems when problems arise.

With the Greek PSI the two major banks of Cyprus initially required about $€ 4$ bil. to satisfy capital requirements. Subsequent estimates by PIMCO taking into account nonperforming loans under deteriorating economic conditions- provided new capital shortfall estimates of 5.98bil. and $8.87 \mathrm{bil}$. under a base and adverse scenario, respectively (PIMCO 2013). These represent $35-55 \%$ of GDP to be added to 2012 public debt of $85.6 \%$ GDP. By comparison, the $€ 85$ bil. Irish rescue package of 2010 amounted to $55 \%$ of the country's GDP to be added to public debt level 65\%. In Ireland the government was in a much better position to deal with the banking crisis that was of the same order of magnitude as the Cyprus crisis- while the public finances of Cyprus did not leave much space. On the other hand the Irish government gave explicit guarantees for all deposits in their banking sector, while the Cyprus government did not.

It is worth noting that the impact on the Cyprus banking sector from the Greek PSI was the highest from all Eurozone countries when expressed as a percentage of the country's GDP, see Table 4.

TABLE 4

Impact of Greek PSI on banking sector of Eurozone countries

\begin{tabular}{lllllll}
\hline & Cyprus & Greece & Germany & Belgium & France & Portugal \\
\hline $\begin{array}{l}\text { Haircut } \\
\text { loss bil. }\end{array}$ & & & & & & \\
euro & 4,14 & 24,3 & 3,6 & 2,1 & 5,04 & 0,42 \\
$\%$ of GDP & 23.03 & 11.65 & 0.14 & 0.56 & 0,25 & 0,25 \\
\hline
\end{tabular}

Source: EBA and author's calculations. 


\section{Debt overhang}

There are different ways to assess the capacity of the country to service its aggregate debt, see, e.g. (McKinsey 2010). International creditors focus primarily on the sustainability of government debt, since it is from the government that they expect to receive back any rescue loans. However, the country should take a holistic view and assess whether the aggregate debt level, aggravated by any rescue package, leads to default on growth even if it avoids a default on debt.

We estimate interest payment on aggregate non-financial debt in Cyprus to be $15-25 \%$ of GDP before the rescue package. Comparing with the Irish economy that is spending circa 15\% of GDP on interest payment we find this level of debt excessive (Gurdgiev 2012). (In February 2013 Ireland negotiated a restructuring of its public debt, exchanging promissory notes of average duration 7 to 8 years and yield $8 \%$, with bonds of average maturity 34 years and yield $3 \%^{7}$ ). Figure 9 illustrates the debt overhang for crisis countries and Germany.

\section{FIGURE 9}

Debt overhang for crisis countries and Germany (Size of bubble= change 2000-2010, \%)

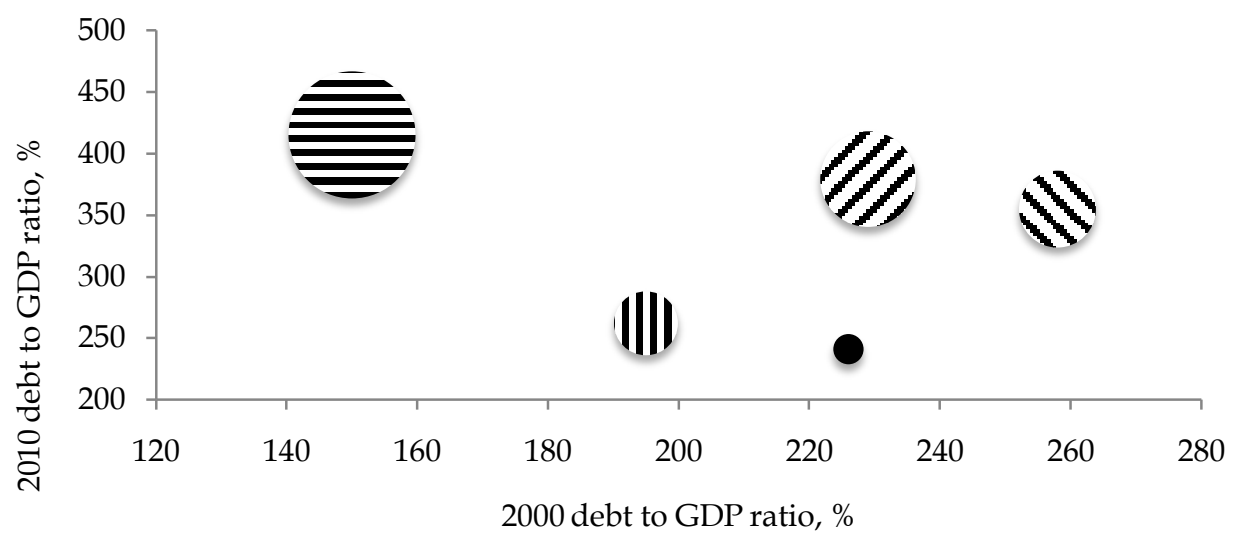

- Germany CCyprus (Greece Spain = Ireland

Source: Authors' calculations for Cyprus and (Gurdgiev 2012, 1-14) for other countries.

7 Ireland Reaches Debt Deal, The Wall Street Journal, 8 Feb. 2013. 
Of course if the economy grows, the percentage of GDP spent on servicing debt declines. None of the evidence examined so far suggests which agent could be the driver of growth. To reinforce the point we carry out an analysis at the aggregate level by applying the BIS model (Cecchetti, Mohanty, and Zampolli 2011) to Cyprus data. Table 5 summarizes the coefficients of the BIS study and we add Cyprus data in the relevant rows to calculate the impact. The analysis shows that the Cyprus debt overhang can cause deflationary stagnation.

\section{TABLE 5}

The real effects of debt

\begin{tabular}{lccc}
\hline & $\begin{array}{c}\text { Debt threshold } \\
\text { estimate } \\
\text { (\% of GDP) }\end{array}$ & $\begin{array}{c}\text { Cyprus debt } \\
\text { (after bank } \\
\text { capitalization) }\end{array}$ & $\begin{array}{c}\text { Weighted impact on } \\
\text { long term growth } \\
\text { (\% GDP loss) }\end{array}$ \\
\hline $\begin{array}{l}\text { Government debt } \\
\text { Baseline }\end{array}$ & $96 \%$ & $140 \%$ & -0.61 \\
$\begin{array}{l}\text { Without crisis } \\
\text { Corporate debt }\end{array}$ & $84 \%$ & & -0.37 \\
$\begin{array}{l}\text { Baseline } \\
\text { Baseline }\end{array}$ & $73 \%$ & $151 \%$ & \\
$\begin{array}{l}2 \text { threshold points) } \\
\text { Without crisis }\end{array}$ & $73 \%, 99 \%$ & & \\
$\begin{array}{l}\text { Household debt } \\
\text { Baseline }\end{array}$ & $73 \%, 88 \%$ & & -0.32 \\
Without crisis & $84 \%$ & $133 \%$ & -1.30 \\
Total & $84 \%$ & $424 \%$ & \\
\hline
\end{tabular}

At current levels of debt we observe a long term impact of $-1.30 \%$ on GDP annually. An almost identical estimate is obtained if we consider the impact of the fiscal adjustment of $5.5 \%$ over the next four years, as stipulated in the MoU, with a fiscal multiplier of 1 . Of course this is not an argument against fiscal adjustments. The drag on growth seems to be approximately the same both in the do-nothing option and in implementing the $\mathrm{MoU}$ and obviously we should try for a solution. This comparison points out that even if we could do away with the MoU we would still pay a penalty for excessive debt, which is about the same with the austerity measures. Experience from other crises also shows that during the three years following a banking crisis the government debt increased on average by $86 \%$, which is significantly more than the needs of the banking sector, due to the ensuing recession (RR, p. 142). Therefore, any way we approach the problem, through debt overhang or through austerity measures or based on the experience of others, stagnation awaits. Something more is needed. But what that might be? 
Can the crisis be resolved through export led growth? If leverage was used to increase exports, then the momentum of exports could perhaps overcome debt overhang. If debt had been used in investments to improve economic growth, it wouldn't have been a problem: an economy that grows faster than its debt is using wisely the borrowed money.

The data show that this is not the case. Cyprus had negative current accounts balance for more than a decade, averaging -5.7\% of GDP since 1995 and $-10.5 \%$ for the five-year period before the crisis, see Figure 10.

FIGURE 10

Current accounts balance

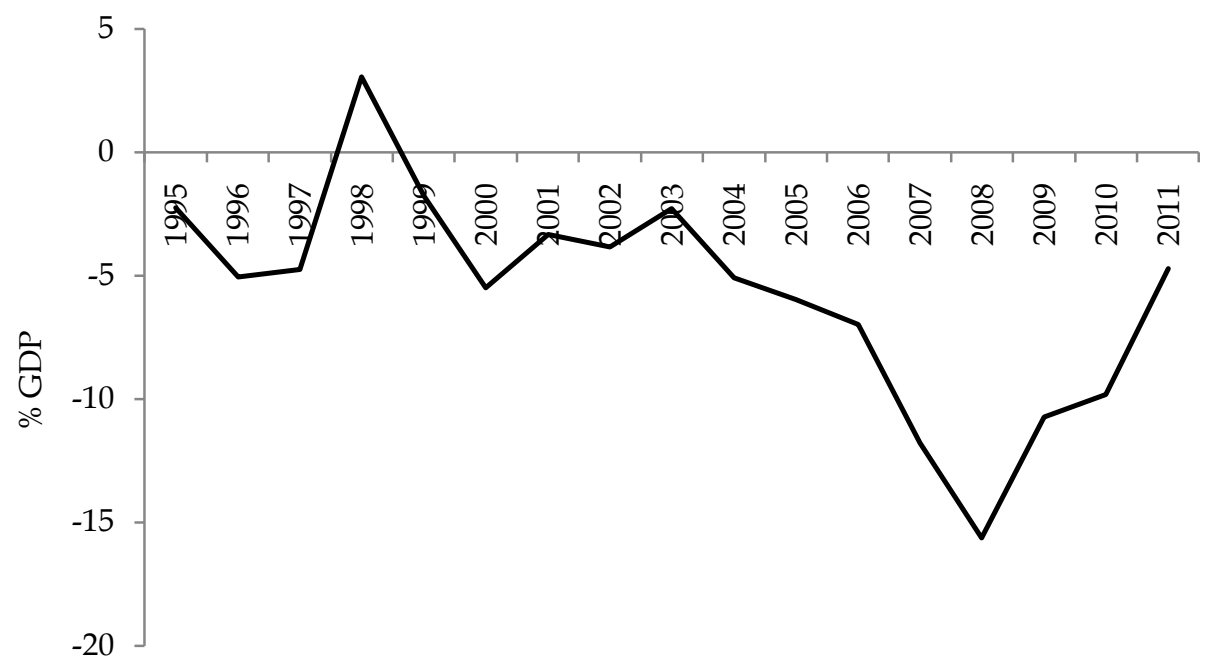

Source: Eurostat.

The cumulative balance of $-68 \%$ since 2000 is surpassed only by Greece from the crises countries. Spain performs better and Ireland significantly so $^{8}$. Compare also with data from (RR, Figure 13.5) for the five-year periods prior to banking crises:

- For advanced economies: $-2 \%$ to $-3 \%$ of GDP

- For the USA (five years prior to 2008 crisis): $-5 \%$ to $-6 \%$ of GDP

We also note from Figure 11 a severe deterioration of the country's net international investment position. This has not been a simple relationship of reducing NIIP to finance consumption. For the five years leading to the crisis the NIIP declined from $+11.7 \%$ to $-71.3 \%$ of GDP. This decline

8 Comparison with other countries from Gurdgiev (2012), Chart D. 
exceeded the deficit consumption needs and is due to worsening international prices and exchange rates and losses from Greek sovereign debt holdings.

\section{FIGURE 11}

Net international investment position of crises countries

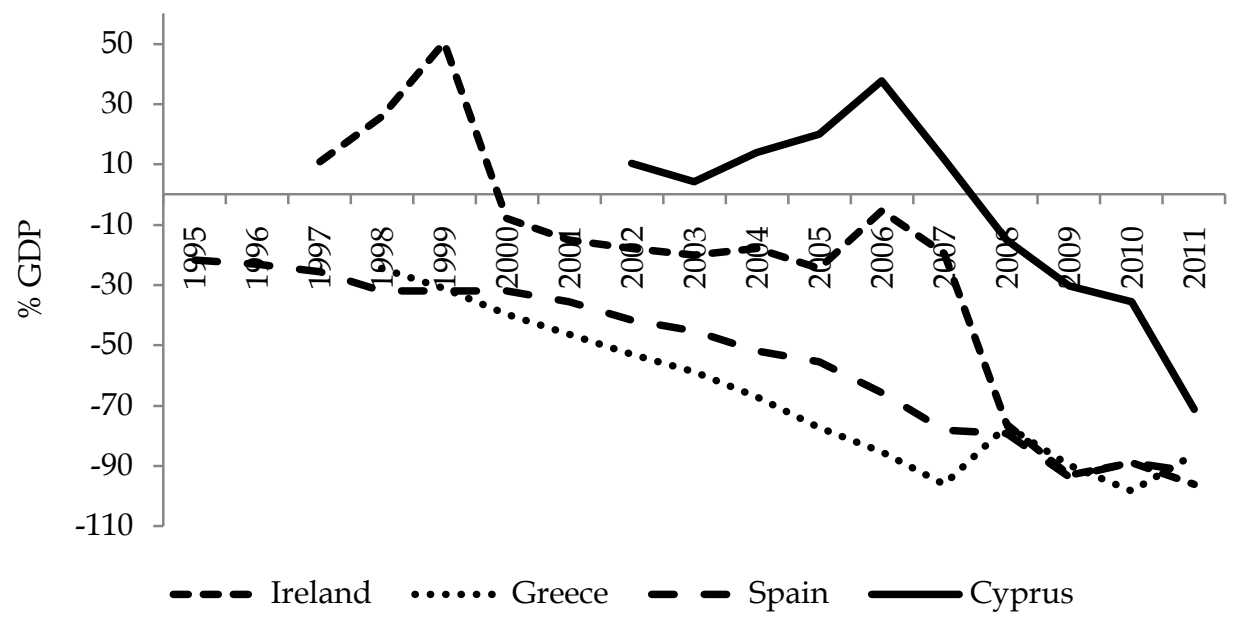

Source: Eurostat.

In a nutshell, the country's balance sheet was deteriorating for reasons beyond its control just as the country was increasing it spending. This is an important point: to a large extend the Cyprus crisis was inherited from the political decision for PSI of the Greek government debt without due consideration for burden sharing among the Eurozone banks. Cyprus banks got a disproportionately large hit from the Greek haircut.

\section{Competitiveness}

What are the prospects of reversing current accounts imbalance? If the country's competitiveness had been improving we may expect to see improvements in the current accounts deficit. Figure 12 shows exactly the opposite. Giving a rating of 100 to the most competitive country from the World Economic Forum rankings and plotting distances from the leader we observe Cyprus sliding since 2009. 
FIGURE 12

Declining competitiveness for crisis countries

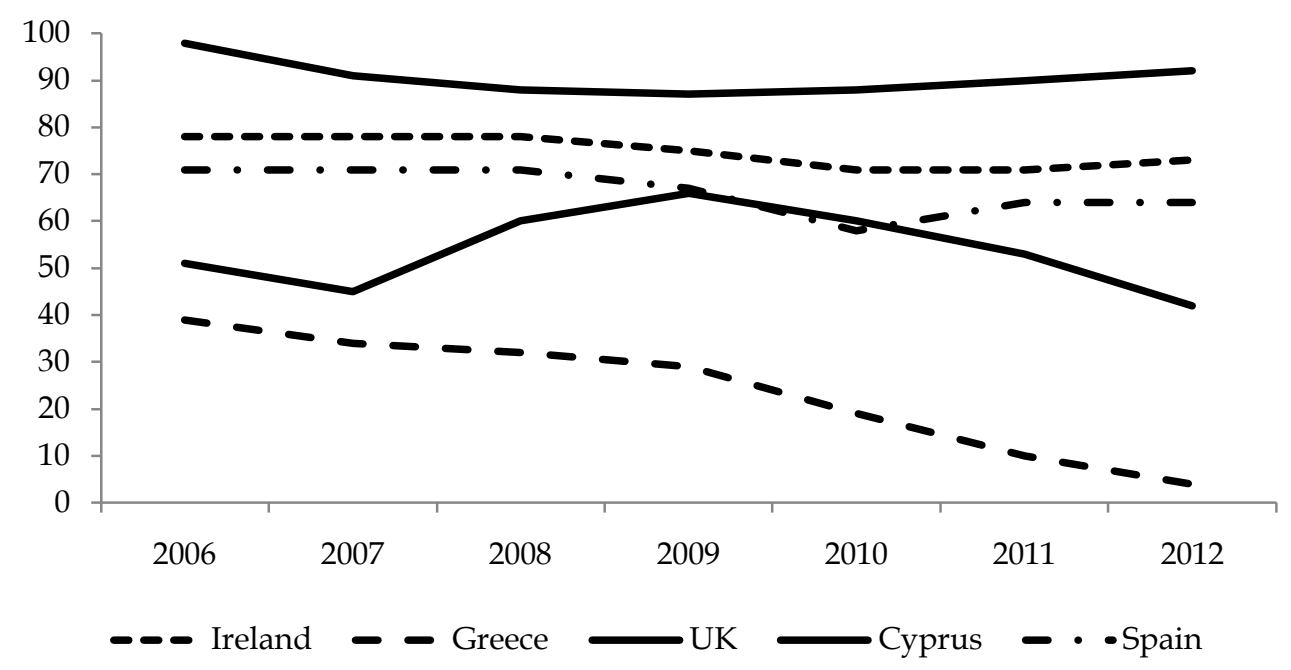

Source: World Economic Forum and author's calculations.

Much is being said about the cost of labor contributing to the loss of competitiveness. Indeed, the figure below shows that unit labor cost increased by almost $20 \%$ more than the EU average since 2000 although inflation was close to the euro area average (IMF November 2011).

One may argue that the increase was in catching up with other EU countries. Indeed, if we were to adjust 2011 compensation per employee for purchase parity we find support for this argument: Cyprus $€ 24,441$, Greece $€ 21,825$, Ireland $€ 33,391$ and Spain $€ 28,246^{\circ}$. However, increases in labor cost must be examined in conjunction with increases in labor productivity. Data from OECD in Figure 14 show that Cyprus productivity improvements did not keep pace. This observation is reinforced from (ILO 2013), Figure 11: from 1999 to 2007 real wages grew by 2\% while labor productivity grew by $0.5 \%$. As the international crisis was developing (2008-2011), productivity declined by $0.5 \%$ and wages grew by $1 \%$.

9 Compensation per employee from ECB, PPP\$ for private consumption from the World Bank. 


\section{FIGURE 13}

Unit labor cost in crisis countries

(Nominal, seasonally adjusted, index 2000=100)

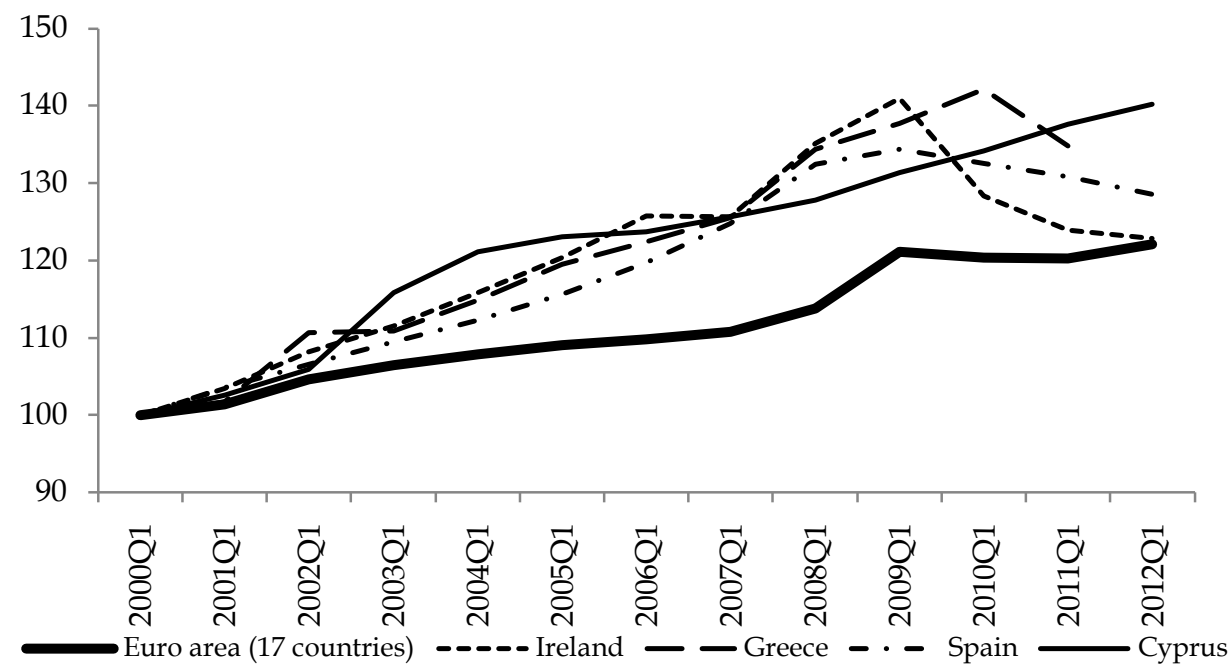

Source: Eurostat.

FIGURE 14

Labor productivity per unit labor input

(Labor productivity of 2000 set to 100)

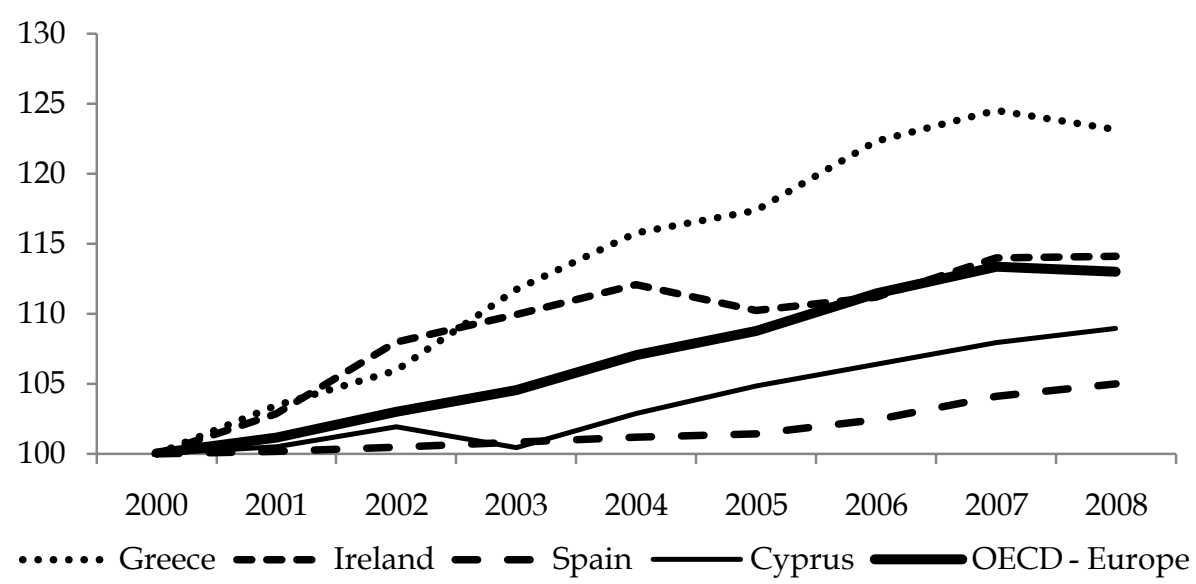

Source: OECD. 
The lag in labor productivity is also manifested in Figure 15 that shows GDP per person employed; Cyprus lags all crisis countries.

\section{FIGURE 15}

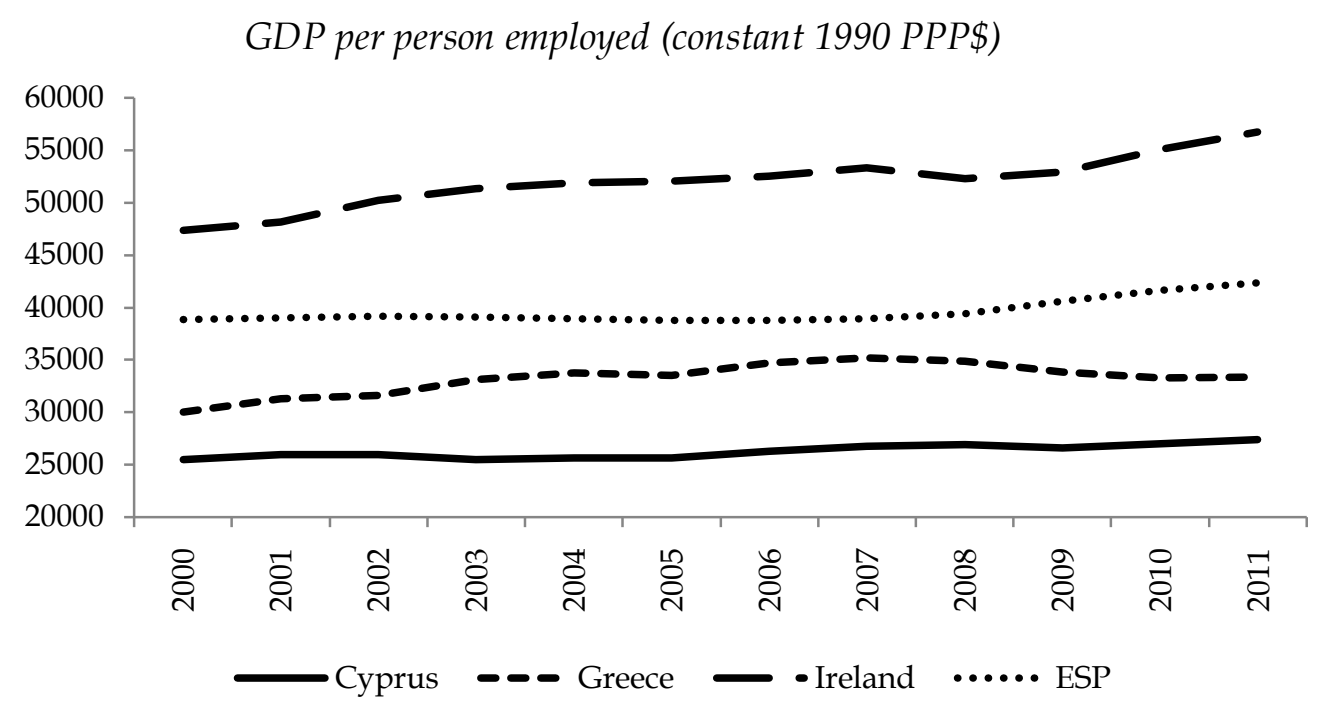

Source: The World Bank.

While much needs to be done to improve labor productivity, it is a mistake to attribute declining competitiveness solely to labor cost. I emphasize this point as it has significant implications on policy. In particular, if high unit labor cost was the sole cause of lack of competitiveness, then an internal devaluation based on wage reduction, painful as it maybe, would have been the appropriate remedy. However, the lack of competitiveness is caused by other factors as well. Cyprus experienced an appreciation of the real effective exchange rate by $10.5 \%$ to $16.75 \%$ which is only partially explained by labor cost, (Commission 2013) Section 3.2.1. Other factors are the increase of commodity prices and energy. Over-indebtedness of the corporate sector has also contributed to declining competitiveness by slowing down investments. Any policy response should address these issues if it is going to be effective.

\section{Solvency in a currency union}

In a currency union the troubled country is deprived the option of devaluation, but it also faces other effects that exacerbate the problem. Within the union the markets have the power to force default upon countries in difficulty and there is no lender of last resort to the sovereigns; see (De Grauwe 2012). 
The events develop as follows: If investors fear that a country can not service or rollover its debt, then spreads increase, bond prices decline and investors sell. This will happen whether the country belongs to a union or not. But if the country has its own currency, the massive sales and the subsequent wish of investors to get rid of their cash, will drive currency exchange rate down, making it unattractive internationally. As de Grauwe puts it, the "currency remains bottled up» in the local market providing liquidity. Some of it may be used to buy again government debt at the higher rates, while the Central Bank can provide the necessary liquidity to fund the government, so default is not a real possibility. In addition the increase in liquidity will increase inflation which «eats away» the debt thus pushing things back to equilibrium.

If the country belongs to a currency union then the sales of its debt will not depress the currency -unless the crisis becomes systemic. The selling investors have cash that can invest in sovereign debt of other union countries. The result is a flight of capital and now the country faces a liquidity crisis in addition to the debt crisis. Lack of liquidity also causes deflation. If many investors get concerned about this cycle and run for cover then they bring about the events they wished to avoid. There is no lender of last resort -the European Central Bank does not play this role for the troubled sovereign- and financial markets have the power to force default. Of course this sequence of events would not have been triggered if the country had sound finances in the first place.

Hence, outside a currency union the events that develop -currency devaluation with the improvement in competitiveness and growth, together with inflation - are automatic stabilizers of debt. These automatic stabilizers do not work in a union and debt should be stabilized by increasing primary surplus. If primary surplus is not possible, the country is insolvent.

Following this line of reasoning de Grauwe compares the solvency of a union with a non-union country (Spain and the UK) and here we extend his analysis for Cyprus. The necessary condition for solvency is that primary budget surplus should be at least as high as the difference between the nominal interest rate and the nominal growth rate times the debt ratio. ${ }^{10}$ To calculate primary surplus in Table 6, I use the pre-crisis 10year Cyprus government bond yield 7\%, compared to 3.5\% and 5\% for UK

10 The formula is $S \geq(r-g) D$, where $S$ is the primary surplus, $r$ is the nominal interest rate on the government debt, $g$ is the nominal growth rate and $D$ is the debt to GDP ratio. 
and Spain, respectively, used by de Grauwe. The average nominal growth rate for Cyprus is 3.06\%, compared to $4.9 \%$ and $1.8 \%$ for UK and Spain. For Cyprus I also provide alternative estimates to stabilize debt at different levels and also include a rescue package with favorable lending rate $3.5 \%$ the effective average rate for the initial Irish rescue program was 5.82\% while the renegotiated long maturity loan of January 13 was around $3 \%$.

From this analysis we see that the country needs to create a primary surplus -this is one aim of the austerity measures. The government primary account balance averaged $-0.3 \%$ of GDP from 1995 to 2011 . For the last three years it averages $-3.5 \%$. Going from $-3.5 \%$ to $+0.61 \%$ requires extraordinary adjustments that are likely to suppress growth. Obviously returning soon to growth of $3.06 \%$ is utterly unrealistic.

TABLE 6

Primary surplus needed to stabilize debt at different levels

Base case benchmarks

UK - 2011 level

Spain - 2011 level

2.30

Cyprus - 2011 level

2.80

Cyprus under different scenarios at recent nominal growth rate of 3.06\%

With debt at the 2012 level of $85.8 \%$ GDP

With debt $100 \%$ of GDP as projected by IMF post bail-in

agreement of euro group March 2013

With $3.5 \%$ interest and debt $140 \%$ of GDP as projected by

Ministry of Finance ${ }^{11}$

How likely are then austerity measures to succeed over the next three years? Assuming nominal growth of $0 \%$ (an optimistic assumption), a borrowing rate $3.5 \%$ and debt $100 \%$ of GDP as projected by IMF after the agreement of Eurogroup of March 2013 the required primary surplus is $3.5 \%$ of GDP. This could have been achieved with the fiscal adjustment of $5.5 \%$ incorporated in the preliminary MoU only if government was running a balanced budget (in which case of course we would have had no problem to solve!). If we now wish (under an optimistic scenario of constant GDP) to achieve a primary surplus of $2 \%$ (i.e., to increase the current primary deficit of $-3.5 \%$ by $5.5 \%$ which is the austerity package) then the interest on debt should be $2 \%$ which is below market rates. This is

11 Presentation of A. Charalambous, CY Ministry of Finance, to the EU Ambassadors, Jan. 2013. 
tantamount to debt relief and debt restructuring unavoidably enters the arsenal of policy options.

We recap that austerity measures alone are unlikely to succeed and some other policy options must be explored.

\section{Is Cyprus like Greece, Ireland or Spain?}

Cyprus is sometimes being compared with Greece but if one looks at the magnitude of the bailout for the banking sector, Ireland appears the appropriate analogy. Some comparisons are made with Spain that also experienced a real estate bubble. To shed some light to these comparisons we look at the debt structure of these countries in Figure 16 (for Cyprus we use 2011 data and include a $€ 10.1$ bil. rescue package

\section{FIGURE 16}

Debt structure by economic agent in \% GDP

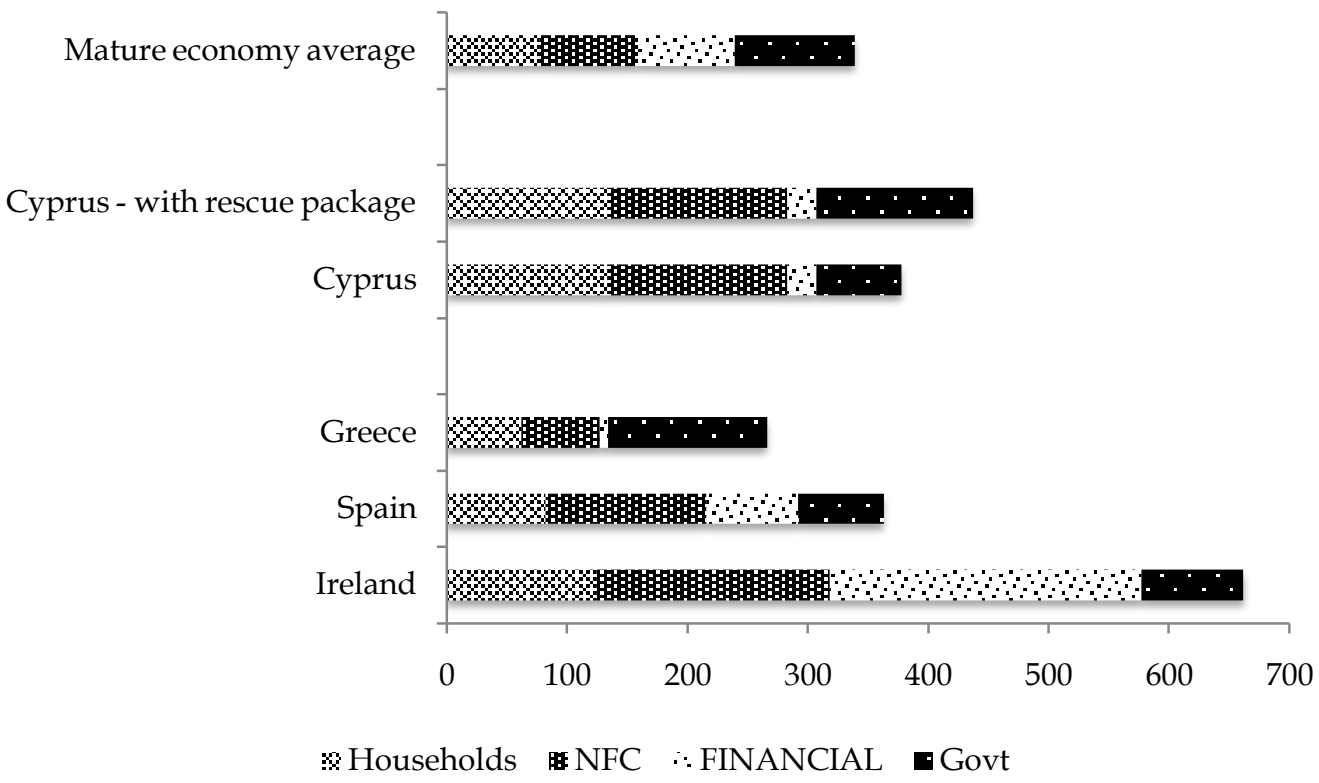

Source: Eurostat for Cyprus and the rest from Exhibit E4 of (McKinsey 2012).

What does this comparison tell us?

1. Cyprus aggregate debt/GDP is larger than that of Greece and Spain. This is the case even without bank recapitalization. 
2. The government contribution to the country's debt is higher than Ireland's although significantly lower than Greece. This is the case even without bank recapitalization.

3. Cyprus corporate and household debt exceeds by $50 \mathrm{pp}$ the debt of mature economies and 10-50pp that of crisis countries.

\section{Summary of the situation}

The situation in Cyprus can be summarized as follows:

1. Debt of non-financial corporations and households is a drag on growth and is significantly higher than in other crisis countries.

2. Government debt is a drag on growth and is higher than in Ireland, similar to Spain but not as high as in Greece.

3. Banking sector problems are of the same order of magnitude as Ireland and dominate the government debt problems.

The stage for the Cyprus crisis was set by excessive corporate and household debt as well as public finance problems. It was triggered by a banking crisis caused first by a public debt crisis in Greece and subsequently, through contagion, by non-performing loans in Cyprus and Greece.

In addition to the present crisis, the country is facing medium- and longterm implied debts for aging. The country has one of the youngest populations in the EU, but an IMF report (Velculescu 2010) finds that it has the worse negative net worth among EU countries when accounting for the cost of aging. It needs to make significantly larger adjustments than Ireland or Spain to address this obligation.

Under these conditions the criteria applied by the European Commission on fiscal sustainability give Cyprus almost a perfect score on each one of the three dimensions of Figure 17; A value 100 denotes severe difficulties.

Our analysis reveals the ingredients of a perfect crisis: all agents of the economy are over-indebted and the banking sector faces a liquidity -if not outright insolvency for one bank - crisis. At the same time the country lags in competitiveness to grow out of its debt. 
FIGURE 17

The fiscal sustainability of Cyprus

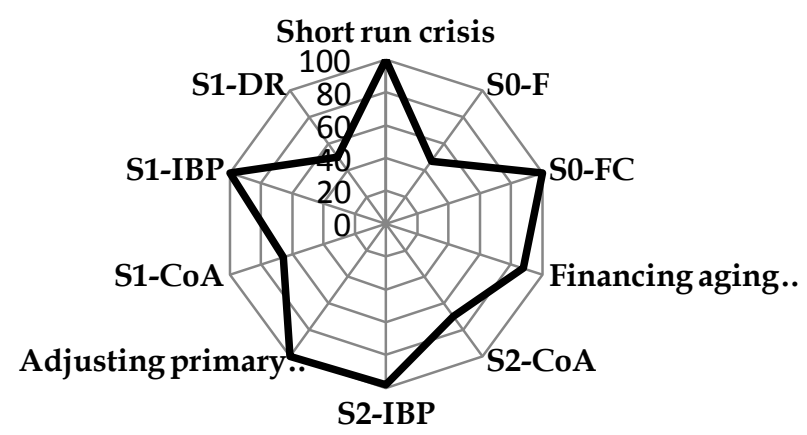

Source: Fiscal sustainability report, (European Commission 2012), Graph 7.10. The scale for each variable corresponds to the range of the data in the EU (highest value of all countries: $100 \%$, lowest: $0 \%$ ). The higher the sustainability risks are, in relative terms, the higher are the values (closer to the outer area of the chart). Legend: COA: ageing cost component, IBP: Initial budgetary position component, DR: debt requirement component, F: fiscal subindex, FC: financial-competitiveness subindex. S0 denotes short run crisis, S1difficulties in adjusting primary account balances and $\mathrm{S} 2$ difficulties in financing an aging population.

But the most significant point that is overlooked is this: Cyprus has amassed a large external debt that cannot be repaid no matter what fraction of the country's domestic economic output is appropriated through austerity measures. Revenues can only repay external debt to the extent that they accrue from exports, or if foreign creditors use payments to acquire domestic goods, services or assets. If this is not the case, then there is an inconsistency between flow of funds and flow of goods and services that ultimately will lead to default. But this turn of events is not unavoidable and we turn now to policy options.

\section{A way forward}

To deal with the complexity of the crisis, policy choices are needed to deleverage corporate and public debt, reconcile household positive net worth with high indebtedness, address the banking problems and restore competitiveness.

Given the magnitude of the debt relative to GDP, the necessary adjustments are large. But as Paul Krugman notes "large deleveraging shocks land the economy in a world of topsy-turvy, where many of the 
usual rules no longer apply. The traditional but long neglected paradox of thrift -in which attempts to save more end up reducing aggregate savingsis joined by the "paradox of toil" -in which increased potential output reduces actual output, and the "paradox of flexibility" - in which a greater willingness of workers to accept wage cuts actually increases unemployment." (Krugman 2010).

Therefore we argue for a policy response that addresses various imbalances simultaneously. Instead of focusing solely on the government debt-banking crisis problem, we should aim for simultaneous improvements to restore balance to the overall economy.

This suggestion is based on the premise that an optimal response to the government debt problem alone is likely to be an extreme solution with a significant adverse effects on other aspects of the Cyprus crisis problem. Similarly for drastic solutions to the banking problems. In satisfying the "usual rules that no longer apply"we are likely to violate the unusual rules that do apply.

From linear programming we know that an optimal solution is on the boundary. Hence, it maximally violates any constrains that were not included in the model formulation but are nevertheless part of the problem. A "suboptimal" solution to the model is less likely to violate important real-world constraints. Similarly, as a partial equilibrium model formulation, an optimally calculated equilibrium for part of the problem is likely to produce maximal disequilibrium for other parts of the problem. In tightly constrained and unstable situations -like an economy in extreme disequilibrium- these considerations are not technical trivialities.

Also, medical professionals tell us that in a critical illness one does not aim at restoring full health of some organs, perhaps ignoring others or even causing adverse side effects, but instead aims for continuous improvements here and there, edging the overall system towards normalcy, allowing the system to utilize its own internal stabilizing mechanisms that are not always fully understood. An economy should be viewed as an organic system.

With the economy in a perfect crisis, a comprehensive response should address multiple dimensions of the problem with continuous monitoring of vital signals -leverage and deficits, growth and employment, competitiveness- for improvements or deteriorations. In the former case do nothing, in the later adjust the policy mix. 
Sweden and Finland provided a role model for dealing with severe deleveraging episodes: they aimed at reviving growth through important structural reforms that shifted their economies from relying mostly on consumption to a growth model in which exports, investment and consumption were more balanced. Swift restoring of stability in the banking system was also a key goal of their policy response. However the government sector was not over-indebted when a banking crisis hit these countries. Cyprus would require assistance in public debt deleveraging to create the necessary fiscal space allowing for a shift of its growth model. This could be done with a combination of debt restructuring and privatizations.

In essence I argue for applying superior forces to the crisis that can then be scaled back if needed, instead of incremental steps that exhaust the available firepower without (perhaps) solving the problem. Such an approach was dubbed the "Colin Powell doctrine of economic policy» in a different context, that of designing expansionary fiscal policy, by US economists Gene Sperling and Lawrence Summers in response to the 2008 crisis It was advocated by Nobel laureates Joseph Stieglitz and Paul Krugman and was proven effective by the Obama administration during his first term in office ${ }^{12}$. Of course Cyprus cannot spend its way out of its debts but the need for decisive action applies.

\section{Policy options}

The following are building blocks for a policy response. For each one I explain the dimension of the problem it addresses but also potential adverse effects, and then discuss how a comprehensive policy agenda could be designed. The details are of essence but it is beyond my objective to provide a full analysis. I argue instead why each policy is relevant and highlight the issues that need to be addressed for full specification.

1. Austerity deleveraging: reduces public spending in pursuit of primary surplus but if excessive may lead to deflationary stagnation.

2. Structural reforms: improve competitiveness but create short-term dislocations with adverse effects on employment and growth and, if not resolved decisively, long-term social costs.

3. Financial innovations: create liquidity in illiquid markets and improve risk sharing, thus allowing market forces to eliminate

12 “The Legacy of Larry Summers." The Economist, December 13, 2010.

http://www.economist.com/blogs/freeexchange/2010/12/american_economic_policy_0 
inefficiencies, but with unintended consequences if not regulated carefully.

4. Selective privatizations: upfront measures that raise funds to repay debt and, if done right, improve competitiveness, but should not be done under fire sale conditions.

5. Debt restructuring: reduces debt burden but with unpredictable adverse effects if debt is internal or if done in a disorderly fashion.

\section{Option 1: Austerity deleveraging}

The austerity measures are agreed in the preliminary MoU. We have already seen that the adjustments are likely to lead to a deflationary spiral. The IMF argues that Cyprus debt is unsustainable and the government responds by reassessing the amount needed for banks to bring it below $€ 10.1$ bil. and make debt to GDP ratio $120 \%$ which is a «magic» threshold for sustainability used by the IMF. However, debt sustainability does not hinge on a single number about bank recapitalization needs. Whether that number is $€ 10.1 \mathrm{bil}$. or $€ 9 \mathrm{bil}$. it will not solve the debt overhang of corporations and households; direct recapitalization of banks will not restore competitiveness. Even with the IMF definition serious doubts are cast on the sustainability of Cyprus debt, see, e.g., (Sterne 2013).

The public debate should focus on the sustainability of overall debt and not only on the pubic debt around a threshold of dubious validity. Aiming for the wrong benchmark we end up not solving the real problem. Austerity should not be uniform with the sole aim of increasing revenues to pay debts. It should be tested instead for its contribution to eliminating some underlying imbalance. In particular, austerity measures should not touch projects with development potential. For instance, road construction or construction of retail outlets does not contribute to growth of a country without much internal trade and significant trade imbalances. It simply creates jobs for the duration of construction. Diverting the earmarked budget to building information highways or into venture capital for entrepreneurship or to research and development $R \& D$ promotes growth. Similarly, a freeze in the development of universities perpetuates an imbalance as the majority of Cypriot students study overseas. On the other hand, aid austerity for students may affect negatively those studying locally, but diverting the saved resources to attract more students to Cyprus universities promotes growth. 


\section{Option 2: Structural reforms}

Many authors have been arguing that the Cyprus economy is in need of reforms in order to (i) improve efficiency of the civil sector, (ii) improve the environment for competition, and (iii) improve efficiency of the labor market. Reforms in the financial markets are discussed separately in the next subsection. The general arguments are well understood and widely accepted and some reforms have been imposed by the MoU13. A recent study (OECD 2012) argues forcefully with empirical support that structural reforms can have an impact sooner than later and are not always accompanied by short term adverse effects .

However, the reforms are in need for a strategy. To what end the reforms? To improve competitiveness of the economy, is the usual answer. But if we stay committed to the current model of the economy -and that is precisely where vested interests put pressure-- we should not expect significant improvements. No matter how much we improve, let us say, the Ministry of Industry, it is unlikely we will see a reversal in the fortunes of the manufacturing industry when Cyprus has no raw materials and our energy imports are the highest in Europe. As I have argued elsewhere (Zenios 2012) we need an economic model that decouples the economy from the use of natural resources -of which, except the sun and now natural gas, we have none-and focuses on high value added activities that capitalize the use of human resources and create more jobs per unit contribution to GDP. See for instance (Mullen and Theodotou 2012; Theodotou 2012) for extensive data-driven research to substantiate the potential of professional services and entrepreneurship in pulling the economy out of its current slump.

Hence, what is needed is a comprehensive Reform Agenda for Competitiveness to unleash private sector growth.

\section{Option 3 : Financial innovations}

Innovative financial instruments allow for better risk sharing, improve market efficiency and facilitate the Schumpeterian «creative destruction». In the context of the current crisis two types of financial innovations could provide liquidity and improve efficiency.

\footnotetext{
13 See, the position paper by political action group ELEFTHERIA, «The Cyprus economy: realities and choices», 19 Sept. 2012, http://www.eleftheria-cy.org/\#!proposals/cpq4 or (Clerides 2012).
} 
First, real estate investment trusts (REIT) could bring liquidity to the commercial real-estate market and assist the corporate deleveraging process. REITs decouple ownership of real estate from use and therefore can assist over indebted borrowers to deleverage without social or business disruptions. Loosing ownership of a factory facility that one can not afford, does not have to imply losing the business with the commensurate loss of jobs and output. There is international evidence that those REITs that stayed true to their mission of leasing real-estate suffered modest losses from the 2008 crisis and today are leading recovery (Lehman and Roth 2010). To activate this tool we need the appropriate legal framework that provides tax incentives for REITs to buy and lease property while profits are distributed as dividend that is taxed. It also requires reforms in the issue of titles, transfer of mortgaged property and low (or zero) transaction cost when property is transferred for the purpose of leasing. Conditions should safeguard that liquidity is created for the purpose of leasing and not for land development to fuel a new bubble. The legislation should discourage speculative investments and reward long term liquidation of over indebted commercial real estate. (For instance: require REITs to be registered companies in Cyprus with substantial equity capital, with capital dispersion among stockowners, restrict ownership by banks, limit turnover to medium or long term horizons). It is worth noting here that China -a potential market for local real estate- has been developing its REIT framework since 2009.

Second, we should keep in sight financial innovations that could address some of the problems in the banking sector. For instance, a secondary market for IOUs could speedup resolution of insolvent corporations. Exchanging part of unsecured bank deposits with interest bearing certificates of deposit with long maturities allows sharing of the banking sector capitalization needs between the taxpayer and depositors. It also gives room for non-EU countries to participate in a rescue package, if they wish, by stepping in to buy such certificates. Of course this is tantamount to bailing-in liabilities, an idea that has been proposed by the Financial Stability Board and the EC as part of a wider design for systemic financial institutions (KPMG, 2012). This should be weighted by political as well as economic criteria and, in particular, the impact such tools could have on the professional services sector. However, a pure policy whereby local taxpayers absorb all the losses will not work at current levels of indebtedness.

Finally, fiscal devaluation allows us to mimic a currency devaluation without the stickiness problems of internal devaluation through wage reductions. Fiscal devaluation shifts social contributions to consumption 
taxes, thus enhancing business competitiveness and discouraging imports. It has been advocated as an appropriate response to the Greek crisis by Domingo Cavallo, former Minister of Finance and chairman of the Central Bank of Argentina, and for curing Eurozone ills by IMF staff (de Mooij and Keen 2012). It was implemented by Denmark in 1988, Sweden in 1993 and Germany in 2006. While the theoretical conditions in (Farhi, Gita, and Oleg 2012) apply to the case of Cyprus, the structure of the economy is such that no gains can be expected from this approach. However, its guiding principles should be kept in mind when discussing VAT adjustments. These should not aim solely to increasing government revenues but to encouraging exports and discouraging imports. Recently I had argued for the use of taxation as a means to reducing the country's ecological footprint -another key factor for competitiveness (Zenios 2012)- and other growth-friendly tax reforms are discussed in (OECD, 2012).

\section{Option 4: Selective privatizations}

Privatization of state owned enterprises has been a contested point in Cyprus policy debates. In the MoU the Government negotiated that privatization will be considered only as a last resort if debt is unsustainable. During the 2013 presidential elections two of the candidates came strongly against privatization while the conservative party candidate (and eventual winner) watered down his long standing policy to accommodate the junior center-party coalition partner.

However, the debate has been framed as one of selling profitable organizations-telecommunications, electricity or port enterprises- to pay debt, instead of looking at privatization as a driver of competitiveness and growth. In the former sense, the political system is right in objecting to sales under current conditions. In the later sense, it should welcome privatization as part of a reform agenda. A World Bank study shows that a $5 \%$ increase in efficiency of state owned enterprises in developing countries could produce savings of $1-5 \%$ of GDP; this would make a significant dent to the Cyprus debt problem (Vagliasindi 2008).

If the country successfully negotiates some fiscal space to manage its debt then a strategy of selective privatizations could be designed whereby several enterprises are offered for privatization with the provision that only one will be sold. This increases competition among buyers from diverse industries to make a fair offer for their sector (e.g., telecoms) otherwise they run the risk of loosing out if other sectors (e.g., ports) receive offers closer to what the government considers fair market value. 
With a multifaceted policy response the country has more degrees of freedom for successful negotiations and this leads to the final option.

\section{Option 5: Debt restructuring}

Debt restructuring is unquestionably part of deleveraging strategies and we argue that it should be incorporated in a policy response to the current crisis; see (IMF 2013) for a very timely policy report. Three criteria apply in deciding debt restructuring:

1. Economic and legal criterion: Is the debt sustainable or not? What would be the impact of restructuring on the deleveraging process? Is there a legal way for implementing restructuring?

2. Political criterion: This is based on the negotiating power of the various parties as to who should carry the cost of restructuring.

3. An "ideological" criterion: It says, for instance, as in Argentina, "We will not pay vulture funds" and "So, sue us!", or, as in EU countries, that no euro country defaults on its debt. ${ }^{14}$

We have seen that the situation is unlikely to be sustainable. Debt overhang is severe for all economic agents and competitiveness will not improve if the country goes into a deflationary spiral, unable to invest in productivity gains. One could, of course, kick the can down the road and hope that when the situation blows up the debt will not be in their hands. Unfortunately, the road always runs through Cypriot territory and we argue for the exact opposite strategy: offer the country debt relief in exchange for future upside potential for the creditors.

The available policy option, then, is debt restructuring with the exchange of existing debt for new securities with longer maturities and a coupon tied to the GDP of the country. GDP-linked bonds have received attention for their stabilizing influence on government finances (coupon payments fall in a recession with declining tax revenues), see (Darvas 2012; Kamstra and Shiller 2009; Datz 2012; Griffith-Jones and Sharma 2006; Miyajima 2006). The prospects of exploitation of natural gas in Cyprus could creditenhance the country's GDP-indexed bonds providing attractive yields.

Any debt restructuring should take into consideration the fact that government debt is held largely by internal creditors, mostly banks. Hence, it should be done in a way that does not affect capitalization needs. Restructuring internal debt by extending maturities without writing down

14 The quotes are from press headlines by Argentinean politicians. 
face value could avoid significant costs for the official sector and it is estimated that $€ 6$ bil. could be rolled over avoiding mark-to-market accounting. In the same spirit one could treat external creditors (e.g., restructuring the Russian loan) and this can be made palatable by offering future expected growth in exchange for current payment freeze. The potential bailing in of creditors discussed earlier could be counterbalanced with involvement of the official sector of those creditors domicile. This policy was adopted by Iceland, alas in a unilateral and chaotic fashion. In the case of Cyprus it could be done orderly setting a successful precedent of fair burden sharing. In particular burden sharing should be in proportion to blame and to excess returns gained from the policies of the past that brought the country to its current predicament. Accounting for blame takes care of the moral hazard issue. Accounting for excess returns improves economic efficiency. As we have seen from the data about one third of the bank's rescue package is due to the Greek haircut for which the local taxpayer bears no responsibility and about one third of the deposits to be rescued by a bank bailout are foreign deposits. Hence a debt restructuring would be fair if it keeps this proportion in mind.

Debt restructuring is not deus ex machina. Negotiating successfully the political criterion depends on the credibility of the country in implementing other measures from the policy options above as well as progress in exploitation of natural gas. If the country addresses its insolvency risks through structural reforms and selective privatizations, and implements (non deflationary) austerity measures, it should receive assistance on its path to growth through debt restructuring.

Of course, any debt restructuring should be orderly and preeminent sovereign debt legal experts tells us that Cyprus has options, (Buchheit and Gulati 2012; Buchheit, Gulati, and Tirado 2013, Buchheit and Gulati $2013 b)^{15}$.

\section{How long will it take?}

In the long run «this too shall pass», but as John Manyard Keynes famously quipped «in the long run we are all dead». The question of duration is not so much in asking «How long will we suffer?» but in avoiding a protracted crisis with permanent loss of output. As much as we are concerned whether a young man or woman will suffer the pains of unemployment for one month or one year, we should be much more

\footnotetext{
15 See also their editorial http://www.voxeu.org/article/walking-back-cyprus.
} 
concerned that by the time the economy starts creating jobs he or she will be the unemployable member of a «lost generation».

Can we give an educated guess of how long this will take? Cyprus is still going through the debt-piling-up phase as the economy goes into recession. Exhibit 4 from (McKinsey 2010) shows estimates that this phase lasts 1 to 2 years; this phase should come to a closure within 2013. After that the process of deleveraging starts that lasts 6 to 7 years, but somewhere in the middle the economy starts growing again. The report finds historical deleveraging episodes «on average lasting six to seven years and reducing the debt to GDP ratio by $25 \%$. GDP typically contracts during the first several years and then it recovers». Growth is expected three years after policy responses are implemented and deleveraging starts. The study of historical episodes in (RR) shows that after banking crises GDP downturn lasts on average two years even as declining employment rates last on average four.

There is big variance around the averages that depends on the resilience of the economy, built in stabilizers and the effectiveness of the policy response. For instance, Sweden suffered declining output for two years after the 1990 crisis and has been enjoying above average growth since then. Japan, on the other hand has been caught in what appears as permanent loss of economic output and has been lagging its historical average for more than a decade.

Evidence suggests that Cyprus could be on the favorable side of these statistics. First, the economy has been proven historically resilient and small positive inflows from the outside world could have a significant impact. (e.g., a few thousand tourist residence sales to the growing Chinese middle class would contribute significantly to deleveraging of land developers). Second, the political system, thus far, has shown remarkable consensus in adopting austerity measures. Even before an MoU was signed, several austerity measures were adopted by unanimous parliamentary decisions with only token union reactions. Third, by 2015 it is possible to complete the designs for natural gas exploitation and then construction work starts and monetization becomes feasible.

Hence, the Cyprus patient can start recovery in two to three years after recognizing the problems and takes the bitter pills of austerity and reforms. Full health can be restored before the end of the decade.

Two caveats on our optimistic outlook. First, the exploitation of natural gas should come as the icing of the cake on a process of reforms to improve 
competitiveness and set the country on a sustainable growth path. It should not be used as a palliative to ease the current crisis and set the stage for the next one. Cyprus should avoid the "curse of natural resources», else it will find itself in the club of serial defaulters. Second, on the domestic political front we note that it is easier to adopt austerity measures and reform if a left government in power is forced by the realities of the economy to do so, while a liberal opposition does not react to measures that are of a liberal ideology. With the recent change of government in Cyprus (the presidency has gone to a center-right coalition) this balance maybe more difficult to maintain and much will depend on the stance of the powerful unions and a large left opposition.

\section{Conclusions: What we learned from other crises}

Many authors discussing the global crisis cite the opening lines from Leo Tolstoy novel Anna Karenina: "Happy families are all alike; every unhappy family is unhappy in its own way". This should be kept in mind as we design policy responses based on the experience of others. So, Lesson No. 1 about learning from past crises is this: Complex systems fail in complex ways and what worked well for others may not apply in the situation at hand; ditto for what failed for others. With this caveat we proceed with four lessons drawn from the literature about the Finish and Swedish crises in the 1990s, (Kiander and Vartia 2011; Schuberth 2011), and the recent experiences in the USA and Iceland:

Lesson 2. The need for decisive action, transparency and political consensus. Rapid, transparent and determined government actions are needed to maintain public confidence in the strength of the banking system and consumer confidence in the economy. Government action reduces the impact of a financial crisis, dampens credit crunch and speeds up recovery. Political consensus reinforces the message.

Lesson 3. Ignorance of financial matters is dangerous. Politicians and economists may have different views of how the economy functions and these differences change before, during and after a crisis. Hence, optimal policy responses are impossible, but economic and market fundamentals should always be kept in sight.

Lesson 4. Normal theories do not apply in abnormal times. During a deep crisis, normal fiscal and monetary policies are not sufficient to 
stabilize the economy and the government and central banks must be ready to act together and with international institutions.

Lesson 5. Crises are followed, sooner or later, by an upturn. Sometimes the upturn has been mild and slow to come, sometimes it has been rapid and strong. Therefore policies should be concerned not only with the acute problems of the crisis but also with the chronic problems that inhibit growth out of the crises. Crises offer an opportunity for shifting resources to more productive sectors and accelerate long-term growth. The crisis is an opportunity to reallocate human capital to new fast growing sectors.

If Cyprus were to follow these lessons, it will find out that another Russian classic, Mikhail Bulgakov from The Master and Margarita ${ }_{\llcorner}$applies: "Everything will turn out right, the world is built on that."

\section{Postscript- the Cyprus crisis after the bail-in}

Eventually the perfect storm of a financial crisis hit the island with full force. On March 17th, and subsequently on March 25th 2013, Eurogroup, the IMF and the ECB reached an agreement with the government of Cyprus on a $€ 10$ billion bailout assistance to the sovereign and a $€ 5$.8billion bail-in for trouble Cyprus banks. ${ }^{16}$

A remarkable first for the Eurozone was the recapitalization of banks through deposits - the so called bail-in. Much has been written in the press on the brutality of the decision and the way it was imposed on the newly elected President. One of the two systemic banks was put into resolution with unsecured depositors standing to loose more than $80 \%$ of their deposits, the other systemic bank was put under a special regime and depositor haircuts are still being calculated in the range of $37 \%$ to $60 \%$, capital controls have been imposed on the country and unemployment jumped to $14 \%$. Remarkably, the March 17th version of the "Cyprus solution" included a haircut on secured depositors and created a worldwide furor that led to the March 25th agreement. There is something positive to be said for bailing-in unsecured depositors and, in the case of Cyprus, saving future generations of taxpayers a burden of 35\% of GDP for

\footnotetext{
16 See the Eurogroup announcement at http://eurozone.europa.eu/newsroom/news/2013/03/eg-statement-cyprus-25-03-13/ and the comprehensive compilation of relevant documents at http://www.economicscyprus.blogspot.com/2013/05/how-to-make-sense-of-cyprusbailout-and.html.
} 
bank bailout. However, bailing-in the depositors of two systemic banks creates significant adverse effects on the economy. Pension and provident funds have been receiving significant haircuts or have been wiped out and the same is true for the working capital of SMEs. Some estimates expect GDP to shrink by $13 \%$ and unemployment to reach $25 \%$. The banking sector size went from over $700 \%$ to $350 \%$ of GDP within a few weeks and this has a significant impact not only on the financial services sector of the economy ( $9 \%$ of the country's GDP) but also on other professional services that were supportive of the banking sector that account $20 \%$ of GDP. It is presently unclear how resilient these sectors will turn out to be.

Some remarks on how these evelopments affect the analysis of the paper:

1. The insolvency of a bank warned about in "Summary of the situation" turned out to be true.

2. The reflexivity of the economy in crisis has bee manifested with a vengeance in the analysis of the bail-in for Bank of Cyprus: the exact magnitude of the unsecured depositors haircut can not be ascertained three months after the decision was made since nonperforming loans are on the rise as a result of the bail-in.

3. The estimates of required primary surplus provided in section "Solvency in a currency union" are unrealistic and should be recalculated assuming a GDP reduction of -5 to $-13 \%$ instead of zero nominal growth.

4. Given the currency controls and the uncertainty surrounding the final bail-in amounts, the financial innovations proposed under policy Option No. 4 are not just a theoretical opinion any more.

5. In conjunction with the above, policy Option No. 5 on debt restructuring becomes even more relevant.

As to how long it will take, we have now very little historical experience to guide us for reasonable estimates and the relevant section of this paper could very well turn out to be overly optimistic.

The two main messages of the paper are reinforced from the recent events: in Cyprus we are witnessing the perfect storm of a crisis and this requires a multi-faceted response. Policy options to deal with a bail-in were discussed in the paper and now that it happened the proposed options become more relevant, especially the need for financial innovations and debt restructuring. 


\section{References}

Blanchard, O., and Leigh, D., (2013) 'Growth forecast errors and fiscal multipliers' International Monetary Fund Working Paper WP/13/1.

Buchheit, L. C., and Gulati M., (2012) 'The Eurozone debt crisis -- The options now' http://papers.ssrn.com/sol3/papers.cfm?abstract id $=2158850$.

------ (2012b) 'Walking back from Cyprus'

http:// papers.ssrn.com/sol3/papers.cfm?abstract id $=2235359$

Buchheit, L. C., Gulati M., and Tirado I., (2013) 'The problem of holdout creditors in Eurozone sovereign debt restructurings' http://papers.ssrn.com/sol3/papers.cfm?abstract_id=2205704.

Cabral, R., (2011) 'The Troika should target the trade and the income balance deficits' http://www.voxeu.org/article/europe-s-policymakers-should-targettrade-and-income-balance-deficits.

Cecchetti, S. G., Mohanty, M. S., and Zampolli, F., (2011) 'The real effects of debt', Bank for International Settlement. http://www.bis.org/publ/othp16.pdf.

Clerides, S., (2012) 'Competition, productivity and competitiveness: Theory, evidence, and an agenda for Cyprus', Cyprus Economic Policy Review 6(2): 81-8.

Darvas, Z., (2012) The Greek Debt Trap: An Escape Plan, Brussels: Bruegel Foundation.

Datz, G., (2012) 'What life after default? Time horizons and the outcome of the Argentine debt restructuring deal', Review of International Political Economy 6(3): $456-84$.

De Grauwe, P., (2012) 'The Governance of a fragile Eurozone', Australian Economic Review 45(3): 255-68.

De Mooij, R., and Keen, M., (2012) 'Fiscal Devaluation" and Fiscal Consolidation: The VAT in Troubled Times, Washington, DC: International Monetary Fund.

European Commission, (2013) 'Macroeconomic imbalances - Cyprus', Occasional Paper 101. ec.europa.eu/economy_finance/publications.com.

Farhi, E., Gita, G., and Oleg, I., (2012) Fiscal Devaluations, Cambridge, MA: National Bureau of Economic Research.

Griffith-Jones, S., and Sharma, K., (2006) 'GDP-indexed bonds: Making it happen', DESA Working Paper 21. www.un.org/esa/desa/papers. 
Gurdgiev, C., (2012) 'Debt restructuring: Orderly, selective and unavoidable', in Debt, Default and Ireland: Essays on the Irish Crisis, 1-14: Wiley-Blackwell.

Herndon, T., Ash, M., and Pollin R., (2013) Does High Public Debt Consistently Stifle Economic Growth? A Critique of Reinhart and Rogoff, University of Massachussets: Political Economy Research Institute.

ILO, (2013) Global Wage Report 2012/13, Geneva.

IMF, (2011) 'Cyprus 2011 article IV consultation', International Monetary Fund Country Report No. 11/331, November 2011.

IMF, (2013) 'Sovereign debt restructuring -recent developments and implications for the fund's legal and policy framework", Washington, DC.: International Monetary Fund, April 2013.

Kamstra, M., and Shiller, R. J., (2009) 'The case for trills: Giving the people and their pension funds a stake in the wealth of the nation', Yale University, New Haven: Cowles Foundation Discussion Paper No. 1717.

Keynes, J. M., (1920) The Economic Consequences of Peace, New York, NY: Cosimo Classics (2005).

Kiander, J., and Vartia P., (2011) 'Lessons from the crisis in Finland and Sweden in the 1990s', Empirica 38 (1): 53-69.

KPMG, (2012) 'Bail-in liabilities: Replacing public subsidy with private insurance', kpmg.com.

Krugman, P., (2010) Debt, Deleveraging, and the Liquidity Trap, Www.Voxeu.Org. http://www.voxeu.org/article/debt-deleveraging-and-liquidity-trap-new-model.

Lehman, R. W., and Roth, H. S., (2010) Global Real Estate Investment Trust Report 2010, Ernst \& Young.

McKinsey Global Institue, (2010) 'Debt and deleveraging. The global credit bubble and its economic consequences', McKinsey Global Institute.

,--- (2012) 'Debt and deleveraging. Uneven progress to growth', McKinsey Global Institute.

Miyajima, K., (2006) How to Evaluate GDP-Linked Warrants -- Price and Repayment Capacity, Washington, DC: International Monetary Fund.

Mody, A., and Sandri D., (2011) The Eurozone Crisis: How Banks and Sovereigns Came to be Joined at the Hip, Washington, DC: International Monetary Fund. 
Mullen, F., and Theodotou M., (2012) Professional Services Driving Jobs and Growth in Cyprus, Nicosia, Cyprus: PWC.

http://www.pwc.com.cy/en/publications/assets/professional-services-reporten.pdf;.

OECD, (2012) Economic Policy Reforms 2012 Going for Growth, OECD Publishing.

Orphanides, A., and Syrichas, G., (2012) Cyprus Economy. Nicosia, Cyprus: Central Bank of Cyprus.

Ostry, J., Ghosh, A., Kim, J., and Qureshi M., (2010) Fiscal Space, Washington, DC: International Monetary Fund.

PIMCO, (2013) Independent due Diligence of the Banking System of Cyprus. file://localhost/Users/zenioss/Library/Application\%20Support/Papers2/Articl es/2013/PIMCO/2013\%20PIMCO.pdf.

Reinhart, C. M., and Rogoff K. S., (2009) This Time is Different: Eight Centuries of Financial Folly, Princeton: Princeton University Press.

Reinhart, C. M., Rogoff, K. S. (2010) 'Growth in a time of debt', NBER Working Paper Series No 15639. http:/ / www.nber.org/papers/w15639.

Schneider, F., Buehm, A., and Montenegro C., (2010) Shadow Economies all Over the World New Estimates for 162 Countries from 1999 to 2007, Washington, DC: The World Bank.

Schuberth, H., (2011) 'Lessons from the crisis in Finland and Sweden in the 1990s by Jaakko Kiander, Pentti Vartia: Comment', Empirica 38(1): 71-6.

Sterne, G., (2013) 'Cyprus: Minefield mapping', Exotix Fixed Income Sovereign Research. http://www.exotix.co.uk/.

Theodotou, M., (2012) Cyprus Entrepreneurship Ecosystem. A Roadmap for Economic Growth. Nicosia, Cyprus: KPMG.

Vagliasindi, M., (2008) Governance Arrangements for State Owned Enterprises, Washington, DC: The World Bank.

Velculescu, D., (2010) Some Uncomfortable Arithmetic regarding Europe's Public Finances, Washington, DC: International Monetary Fund.

Zenios, S. A., (2012) Creative Cyprus. An Agenda for Political Reform for Cyprus in the 21st Century, Athens: PAPAZISIS (in Greek). 